\title{
Application of a Combined Adsorption-Ozonation Process for Phenolic Wastewater Treatment in a Continuous Fixed-Bed Reactor
}

\author{
Cristian Ferreiro ${ }^{1, * \mathbb{D}}$, Ana de Luis ${ }^{2} \mathbb{D}$, Natalia Villota ${ }^{3}$, Jose María Lomas ${ }^{3}$, José Ignacio Lombraña ${ }^{1}$ (D) \\ and Luis Miguel Camarero ${ }^{3}$
}

1 Department of Chemical Engineering, Faculty of Science and Technology, University of the Basque Country UPV/EHU, Barrio Sarriena s/n, 48940 Leioa, Spain; ji.lombrana@ehu.eus

2 Department of Chemical and Environmental Engineering, Faculty of Engineering in Bilbao, University of the Basque Country UPV/EHU, Plaza Ingeniero Torres Quevedo, 1, 48013 Bilbao, Spain; ana.deluis@ehu.eus

3 Department of Environmental and Chemical Engineering, Faculty of Engineering of Vitoria-Gasteiz, University of the Basque Country UPV/EHU, 01006 Vitoria-Gasteiz, Spain; natalia.villota@ehu.eus (N.V.); josemaria.lomas@ehu.eus (J.M.L.); luismiguel.camarero@ehu.eus (L.M.C.)

* Correspondence: cristian.ferreiro@ehu.eus; Tel.: +34-946-012-512

check for

updates

Citation: Ferreiro, C.; de Luis, A.; Villota, N.; Lomas, J.M.; Lombraña, J.I.; Camarero, L.M. Application of a Combined Adsorption-Ozonation Process for Phenolic Wastewater Treatment in a Continuous Fixed-Bed Reactor. Catalysts 2021, 11, 1014. https://doi.org/10.3390/ catal11081014

Academic Editor: Pedro B. Tavares

Received: 26 July 2021

Accepted: 21 August 2021

Published: 22 August 2021

Publisher's Note: MDPI stays neutral with regard to jurisdictional claims in published maps and institutional affiliations.

Copyright: (C) 2021 by the authors. Licensee MDPI, Basel, Switzerland. This article is an open access article distributed under the terms and conditions of the Creative Commons Attribution (CC BY) license (https:// creativecommons.org/licenses/by/ $4.0 /)$.

\begin{abstract}
This work studied the removal of phenol from industrial effluents through catalytic ozonation in the presence of granular activated carbon in a continuous fixed-bed reactor. Phenol was chosen as model pollutant because of its environmental impact and high toxicity. Based on the evolution of total organic carbon (TOC) and phenol concentration, a kinetic model was proposed to study the effect of the operational variables on the combined adsorption-oxidation (Ad/Ox) process. The proposed three-phase model expressed the oxidation phenomena in the liquid and the adsorption and oxidation on the surface of the granular activated carbon in the form of two kinetic constants, $k_{1}$ and $k_{2}$ respectively. The interpretation of the constants allow to study the benefits and behaviour of the use of activated carbon during the ozonisation process under different conditions affecting adsorption, oxidation, and mass transfer. Additionally, the calculated kinetic parameters helped to explain the observed changes in treatment efficiency. The results showed that phenol would be completely removed at an effective contact time of $3.71 \mathrm{~min}$, operating at an alkaline $\mathrm{pH}$ of 11.0 and an ozone gas concentration of $19.0 \mathrm{mg} \mathrm{L}^{-1}$. Under these conditions, a $97.0 \%$ decrease in the initial total organic carbon was observed.
\end{abstract}

Keywords: catalytic ozonation; three-phase modelling; fixed-bed reactor; wastewater treatment; phenol; granular activated carbon; Ad/Ox

\section{Introduction}

Increases in the world population and the industrial revolution have brought many advantages to humanity. However, the intensive use and pollution of natural resources is leading many developed countries on the European and American continents towards an ecological deficit by the first third of the 21st century [1]. For this reason, national governments are encouraging the improvement of manufacturing production processes to increase the efficiency of water resources, as well as raw materials, in order to minimise the environmental impact of goods produced. In the context of water scarcity, the responsible use and management of wastewater is a desirable objective [2].

To safeguard the environment and public health, it is necessary the development and implementation of effective wastewater treatment that allow us to exceed the quality standards regulated by the U.S. Environmental Protection Agency's (EPA) Water Quality Standards Regulation (WQSR) [3] or the Water Framework Directive (Directive 2000/60/EC) of the European Union [4]. This is one of the highest-priority challenges that society must solve in the next decade. In fact, in 2015, the United Nations (UN) included SDG 6 on Clean 
Water and Sanitation in the Sustainable Development Goals (SDGs) for the safe treatment of wastewater, to ensure the availability of water and its sustainable management for future generations [5].

A common example of this type of pollution is phenolic wastewater from the cellulose, oil refining, metallurgical, and plastics industries [6]. Phenol is an EPA priority compound listed on the Contaminant Candidate List 4 (CCL4) [7] of substances that are of high toxicity to humans and aquatic life. In humans, phenol has been reported as a potential source of skin irritation and kidney problems, and it has been associated with leukaemia and other mutagenic diseases [8]. Toxicity levels harmful to humans and aquatic life are between 9 and $25 \mathrm{mg} \mathrm{L}^{-1}$ [9]. In many countries, such as Brazil, its discharge into the environment is limited to a concentration of $0.5 \mathrm{mg} \mathrm{L}^{-1}$ and in the USA, to a concentration of less than $0.001 \mathrm{mg} \mathrm{L}^{-1}$.

Different treatment methods have been proposed for the removal of phenols from wastewater, the most traditional being chemical oxidation by Fenton reaction (100\%) [10], adsorption (26\%) [6], extraction by liquid membrane emulsion (72\%) [11], coagulation and precipitation (36.8\%) [12], or activated sludge (87\%) [9]. Other biological treatments [13], especially enzymatic treatments, using peroxidases (98\%) [14] or tyrosinase (25\%) [15] reduced the phenol concentration after 30 and $2 \mathrm{~h}$ respectively. Activated sludge is one of the most widely used treatments due to its low cost and ease of handling, but it is limited in applicability because the microorganisms, despite prior acclimatisation, are incapable of treating phenol concentrations of more than $100 \mathrm{mg} \mathrm{L}^{-1}$. This is due to the low biodegradability of these effluents and the inhibitory effects that these concentrations of phenol have on the microorganisms [16]. Unfortunately, many wastewaters from chemical and petrochemical industries far exceed these concentrations. For example, in the coke industry and petrochemical plants concentrations in the range of $28-3900 \mathrm{mg} \mathrm{L}^{-1}$ are common [17]. Other treatments based on adsorption on activated carbons could be a feasible alternative. Adsorption is considered one of the most efficient and effective methods to separate emerging pollutants such as diclofenac [18] and petrochemical effluents containing benzene and toluene [19], due to its simplicity and flexibility of use, its high porosity, large specific surface area and, the high degree of surface interactions [20]. However, the presence of organic content in the wastewater could be a potential limitation because it could interfere in pollutants removal efficiency by competing for adsorption active sites on activated carbon [21]. Consequently, given the complexity of typical aqueous effluents in the industry, adsorption alone would not be the most suitable method.

In order to provide efficient solution for the treatment of these effluents, advanced oxidation processes (AOPs) have attracted the interest of many researchers due to their advantages [22,23]. Among the many existing AOPs, ozonation is a process with a high oxidation potential, which can lead to efficient removal of organic compounds, such as pharmaceuticals, personal care products, pesticides, solvents and surfactants, even at low ozone concentrations [24-26]. However, certain groups of organic compounds are particularly refractory to oxidation by ozone, such as carboxylic, oxalic, and pyruvic acids [27].

A combination of ozonisation and adsorption processes with activated carbon (AC) could be more efficient and sustainable treatment for wastewaters containing refractory organic pollutants. Some of the previous studies in which catalytic ozonisation processes with activated carbons were used for the removal of different organic compounds are listed in Table S1. According with Table S1, catalytic ozonation with granular activated carbons (GAC) could overcome the limitations of ozonation due to the adsorption capacity, high surface area, and the catalytic activity.

The catalytic mechanism of ozonisation in the presence of GAC is still unclear, but recent results suggest that the carbon essentially promotes the decomposition of ozone with a consequent increase in the production of radicals. These hydroxyl radicals would not be bound to the surface, remaining free to react in the aqueous phase. Therefore, the activated 
carbon would behave as an initiator of the radical-like chain reaction that transforms ozone into hydroxyl radicals, which in turn react with the organic compounds in the bulk [28].

On the other hand, other authors, such as Nawrocki and Kasprzyk-Hordern [29] and Guo et al. [30], have postulated that the activated carbon initiates the decomposition of ozone into hydroxyl radicals, and then the ozone reacts with the superficial oxygenated groups to generate $\mathrm{H}_{2} \mathrm{O}_{2}$, which in turn reacts with the ozone in the bulk to produce hydroxyl radicals. In other words, in this model, the catalyst plays a dual role during the catalytic ozonisation process. First, it adsorbs and decomposes the ozone, leading to the formation of active species, and then the active species reacts with the non-chemisorbed organic compounds. In addition, the activated carbon adsorbs organic compounds, and then reacts with the oxidising species generated on the catalyst's surface via the Criegee mechanism [31].

These mechanistic reactions of ozone decomposition and radical reactions, depending on the $\mathrm{pH}$ of the medium, can be summarised, according to Beltrán et al. [26]:

- Homogeneous reaction (at the liquid level):

$$
\begin{gathered}
\mathrm{O}_{3}+\mathrm{OH}^{-} \rightarrow \mathrm{HO}_{2}^{-}+\mathrm{O}_{2} \\
\mathrm{O}_{3}+\mathrm{HO}_{2}^{-} \rightarrow \mathrm{HO}_{2}^{\bullet}+\mathrm{O}_{3}^{\bullet-} \\
\mathrm{O}_{3}+\text { Initiator } \rightarrow \mathrm{O}_{3}^{\bullet-}+\text { Initiator }^{+} \\
\mathrm{HO}_{2}^{\bullet} \rightleftarrows \mathrm{O}_{2}^{\bullet-}+\mathrm{H}^{+}
\end{gathered}
$$

- Heterogeneous reactions (at the level of the solid):

For an acid pH:

$$
\begin{gathered}
\mathrm{O}_{3}+\mathrm{GAC} \rightleftarrows \mathrm{O}_{3}-\mathrm{GAC} \\
\mathrm{O}_{3}-\mathrm{GAC} \rightleftarrows \mathrm{O}-\mathrm{GAC}+\mathrm{O}_{2} \\
\mathrm{O}_{3}+\mathrm{O}-\mathrm{GAC} \rightleftarrows 2 \mathrm{O}_{2}+\mathrm{GAC}
\end{gathered}
$$

For an alkaline $\mathrm{pH}$ :

$$
\begin{gathered}
\mathrm{OH}^{-}+\mathrm{GAC} \rightleftarrows \mathrm{OH}-\mathrm{GAC} \\
\mathrm{O}_{3}+\mathrm{OH}-\mathrm{GAC} \rightleftarrows \mathrm{O}_{3}^{\bullet}-\mathrm{GAC}+\mathrm{HO}^{\bullet} \\
\mathrm{O}_{3}+\mathrm{O}^{\bullet}-\mathrm{GAC} \rightleftarrows \mathrm{O}_{2}^{\bullet-}+\mathrm{GAC}+\mathrm{O}_{2}
\end{gathered}
$$

- Homogeneous propagation and termination reactions:

$$
\begin{gathered}
\mathrm{O}_{3}+\mathrm{O}_{2}^{-} \rightarrow \mathrm{O}_{3}^{\bullet-}+\mathrm{O}_{2} \\
\mathrm{O}_{3}^{\bullet-}+\mathrm{H}^{+} \rightarrow \mathrm{HO}_{3}^{\bullet} \\
\mathrm{HO}_{3}^{\bullet} \rightarrow \mathrm{HO}^{\bullet}+\mathrm{O}_{2} \\
\mathrm{HO}_{3}^{\bullet}+\text { Scavenger } \rightarrow \text { Oxidation products }
\end{gathered}
$$

According with this, the integration of a GAC catalyst into a continuous adsorptionozonisation (Ad/Ox) process would lead to a complete removal and mineralisation of phenol containing waters. Ad/Ox process is a complex system involving different aspects, such as mass transfer and radical generation or adsorption equilibria, among others. Few studies deepened the kinetics of the process with the prospect of implementation of this catalytic technology on an industrial scale. Thus, a study of the behaviour of the system operating in a fixed-bed under different operating conditions through a kinetic model could provide the necessary information to achieve the desired final scale-up.

Given the excessive number of variables involved in Ad/Ox process, some of which are unknown, it is impossible to develop a rigorous model, let alone propose a detailed reaction mechanism. Consequently, from a practical point of view, a model employing experimental data derived under different operational conditions can serve as a basis for real applications, as long as the model adequately simulates the experimental data. 
Therefore, this study aimed to develop a three-phase kinetic model of a continuous process in a fixed-bed catalytic ozonation (Ad/Ox) treatment with granular activated carbon (GAC). Phenol was chosen as a model organic pollutant because of its environmental impact, high toxicity, and occurrence in the industry. It has been proposed a kinetic model that includes mass transfer parameters, adsorption equilibria, and reaction rate constants at the solid and liquid surface, to analyze the effect of operating conditions and to identify the operational strategies that will lead to increased degradation and mineralisation rates.

\section{Results and Discussion}

\subsection{Removal of Phenol and Mineralisation}

In order to study the influence of GAC on phenol removal, a preliminary experiment was performed with ozone alone in a fixed-bed reactor, with an inert material (glass spheres) and adsorption or ozonation only in the presence of GAC, in order to evaluate the improvement achieved by activated carbon. The transitory profiles of the primary degradation and mineralisation of the three systems are compared in Figure 1.

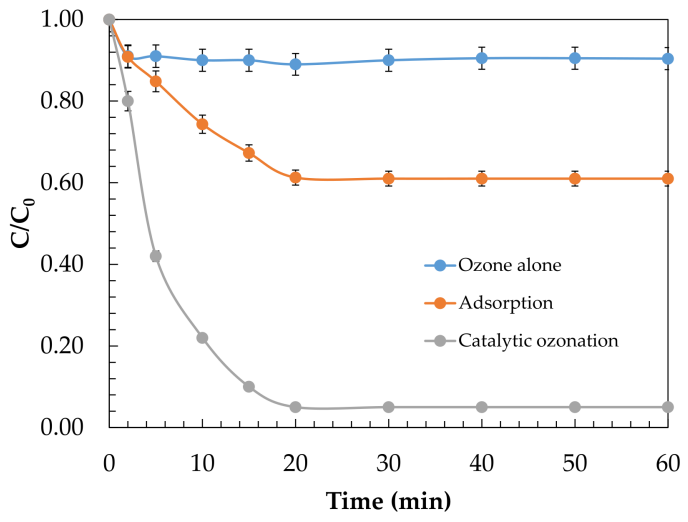

(a)

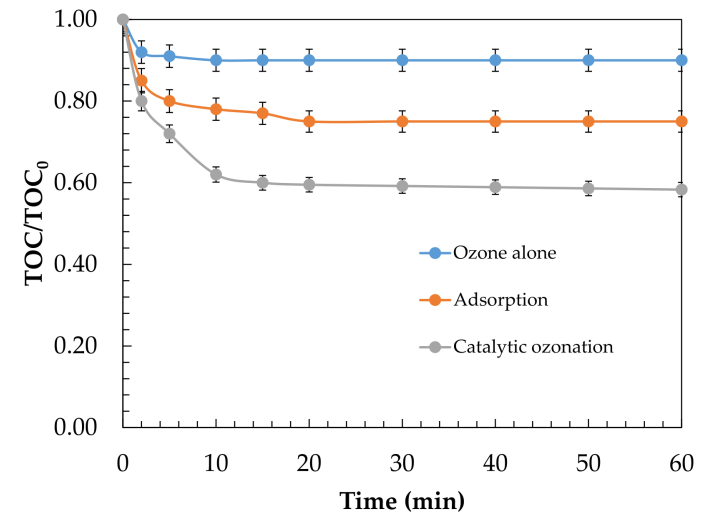

(b)

Figure 1. Comparison of ozonation alone, adsorption, and catalytic ozonation processes with GAC in a fixed-bed reactor for phenol removal. Evolution of (a) primary degradation and (b) mineralisation in terms of TOC. Experimental conditions: $C_{0}=250 \mathrm{mg} \mathrm{L}^{-1} ; Q_{\mathrm{G}}=0.05 \mathrm{~L} \mathrm{~h}^{-1} ; C_{\mathrm{O}_{3}, \mathrm{G}}=12.0 \mathrm{mg} \mathrm{L}^{-1} ; Q_{\mathrm{L}}=12 \mathrm{~mL} \mathrm{~min}^{-1} ; \mathrm{pH}=6.5 ; M_{\mathrm{CAT}}=70.8 \mathrm{~g} \mathrm{~L}^{-1} ; P=1.0 \mathrm{~atm} ;$ $\mathrm{T}=20{ }^{\circ} \mathrm{C} ; V=0.14 \mathrm{~L}$.

Ozonation alone achieved a primary degradation of only $10 \%$ (see Figure 1). This low degradation could be due to the oxidation potential of ozone being lower $\left(\mathrm{E}^{\circ}=2.07 \mathrm{~V}\right)$ than that of the hydroxyl radicals $\left(\mathrm{E}^{\circ}=2.80 \mathrm{~V}\right)$ generated by the indirect reactions associated with the decomposition of ozone in the presence of GAC [22]. The mineralisation of phenol in the catalytic system was more efficient compared with ozonation alone or adsorption, with a $41.7 \%$ mineralisation achieved $20 \mathrm{~min}$ after reaching the steady state.

As can be seen in Figure 1b, the mineralisation obtained by catalytic ozonisation with GAC does not match the sum (35.0\%) of the efficiencies obtained by ozonisation or adsorption with GAC. According to Lin et al. [32], this could be because during the catalytic ozonisation adsorption, reaction, and desorption processes of oxidised pollutants were involved, in contrast to the ozonisation. In overall, the results indicate that GAC had some catalytic activity to increase the generation of oxidative species responsible for the degradation of phenol. This same effect was observed by Xiong et al. [33], who obtained $26.1 \%$ additional mineralisation using the catalytic system with GAC in a basket reactor, compared with adsorption or ozonisation alone. According with their research, the lower molecular weight of the oxidation by-products adsorbed onto the GAC could explain the higher removal obtained in comparison with ozone alone. 


\subsection{Kinetic Model of the Ad/Ox Process Operated in a Continuous Fixed-Bed Reactor}

The implementation of this system on an industrial scale requires predictions of the system's behaviour. Therefore, the development of the three-phase model was based on the considerations made by Ferreiro et al. [17], in which the G-L-S ozone mass transfer, the adsorption process of both ozone and phenol, and the parallel chemical reaction occurring at both the liquid and solid levels were taken into account. The application of the $\mathrm{Ad} / \mathrm{Ox}$ model in a continuous system was based on the following considerations:

- The overall oxidation rate of the process is represented by the ozone consumption in the parallel reaction process (both at the liquid and solid level);

- The oxidation rate of the parallel stages, in the liquid phase and on the GAC, were represented by pseudo-first-order kinetics with respect to phenol;

- The GAC was considered a sufficiently porous material, where the diffusion of ozone and phenol into the catalyst particles took place;

- The adsorption kinetics during the Ad/Ox process are represented by a pseudosecond-order kinetic equation (Equation (20));

- The kinetic constant of phenol removal in the solid incorporates the degradation and desorption of organic compounds;

- The degradation kinetics in both liquids and solids, as well as the adsorption, are influenced by the operational conditions of the ozonisation process.

Taking into account the above, the combined process of the physical adsorption and oxidation of phenol must be described through its correlation with ozone consumption. Therefore, the following expression was defined, which relates the rate of phenol oxidation, $-r_{\mathrm{P}}$, to the ozone consumed:

$$
-r_{P}=-\frac{\mathrm{d} F_{\mathrm{P}}}{\mathrm{d} V}=z \times N_{\mathrm{O}_{3}},
$$

where $z$ is the stoichiometric coefficient of the reaction between transferred ozone and oxidised phenol, $V$ is the bed volume, $F_{\mathrm{P}}$ is the phenol mass flow and $N_{\mathrm{O}_{3}}$ is the total ozone consumption. From the ozone consumption in the liquid $\left(\mathrm{N}^{\mathrm{I}} \mathrm{O}_{3}\right)$ and the production of ozone at the GAC's surface $\left(\mathrm{N}^{\mathrm{II}} \mathrm{O}_{3}\right.$ ), the following expressions (Equations (16)-(18)) were obtained:

$$
\begin{gathered}
N_{\mathrm{O}_{3}}=N_{\mathrm{O}_{3}}^{\mathrm{I}}+N_{\mathrm{O}_{3}}^{\mathrm{II}}=K_{\mathrm{L}} a \times\left(C_{\mathrm{O}_{3}, \mathrm{~L}}^{*}-C_{\mathrm{O}_{3}, \mathrm{~L}}\right) \\
N_{\mathrm{O}_{3}}^{\mathrm{I}}=k_{\mathrm{c}, \mathrm{L}} \times C_{\mathrm{O}_{3}, \mathrm{~L}} \times C_{\mathrm{P}}=k_{\mathrm{c}, \mathrm{L}} \times C_{\mathrm{P}} \times\left(C_{\mathrm{O}_{3}, \mathrm{~L}}-0\right)=k_{\mathrm{c}, \mathrm{L}} \times C_{\mathrm{P}} \times\left(\frac{P_{\mathrm{O}_{3}}^{*}}{H e}-0\right) \\
N_{\mathrm{O}_{3}}^{\mathrm{II}}=k_{\mathrm{c}, \mathrm{S}} \times \frac{C_{\mathrm{O}_{3}, \mathrm{~L}}}{m} \times Z_{\mathrm{P}} \times M_{\mathrm{CAT}}{ }^{\prime}
\end{gathered}
$$

where $K_{\mathrm{L}} a$ is the volumetric ozone mass transfer coefficient, $\mathrm{C}^{*} \mathrm{O}_{3}, \mathrm{~L}$ is the concentration of dissolved ozone in the liquid phase at saturation conditions, $k_{\mathrm{c}, \mathrm{L}}$ is the kinetic constant of the reaction between phenol and ozone at the liquid level, $C_{\mathrm{O}_{3}, \mathrm{~L}}$ is the ozone concentration in the liquid phase, $C_{\mathrm{P}}$ is the phenol concentration, $P^{*} \mathrm{O}_{3}$ is the partial pressure of ozone in equilibrium with the ozone concentration in the liquid phase, He is Henry's constant, $Z_{\mathrm{P}}$ is the concentration of phenol adsorbed on the GAC, and $M_{\mathrm{CAT}}$ is the GAC concentration. Equation (18) assumes that the ozone adsorbed on the solid phase catalyst is in equilibrium with the ozone concentration in the liquid, which can be expressed as $C_{\mathrm{O}_{3}, \mathrm{~L}}=m \times C^{*} \mathrm{O}_{3}, \mathrm{~S}$, where $m$ is the slope of the equilibrium line between the liquid and solid phases.

After the description of the phenol degradation process through ozone consumption, the adsorption equilibrium must have been taken into account in the kinetic model of the $\mathrm{Ad} / \mathrm{Ox}$ process, because the catalytically functional adsorbent used in this system was GAC, a material with high porosity and large available specific surface area. The equilibrium was assumed to be a Freundlich isotherm, in accordance with the adsorption experiments carried out in previous studies of the same GAC [17]. Freundlich equation 
was used because the adsorption step in these systems is usually a quick process [34]. Freundlich's equation is given by the following expression [24]:

$$
\mathrm{Z}_{\mathrm{P}, \infty}=K_{\mathrm{F}} \times C_{\mathrm{P}}^{1 / n_{\mathrm{F}}}
$$

where $Z_{\mathrm{P}, \infty}$ is the concentration of phenol in equilibrium with the concentration of the liquid phase, $K_{\mathrm{F}}$ is the Freundlich constant and $n_{\mathrm{F}}$ is a factor describing the adsorption intensity. Consequently, the kinetics corresponding to the adsorption process could be described through pseudo-second-order kinetics, according to the following equation [35]:

$$
\left(-\frac{\mathrm{d} Z_{\mathrm{P}}}{\mathrm{d} t}\right)_{\mathrm{ads}}=k_{\mathrm{ads}} \times\left(\mathrm{Z}_{\mathrm{P}, \infty}-\mathrm{Z}_{\mathrm{P}}\right)^{2} \times M_{\mathrm{CAT}}
$$

To describe the evolution of the phenol concentration over time at each longitudinal position of the fixed-bed tubular system, It have been used the axial dispersion model of Alhemed et al. [36]. The measurement of axial dispersion considers the possible deviation from ideal flow due to turbulence, as well as changes in bed characteristics and gas presence. For a tubular system, with one-dimensional flow and first-order kinetics, the axial dispersion is given by the following Equation (21):

$$
v \times \frac{\mathrm{d} C_{\mathrm{P}}}{\mathrm{d} L}-D_{\mathrm{L}} \times \frac{\mathrm{d}^{2} C_{\mathrm{P}}}{\mathrm{d} L^{2}}=0
$$

where $D_{\mathrm{L}}$ is the axial dispersion coefficient, $L$ is the length of tubular reactor (GAC bed height), and $v$ is the linear flow velocity of the fluid. Through Equations (19)-(21), the overall velocity, incorporating the kinetic terms of adsorption, chemical reaction and dispersion, can be inferred from the following general expression:

$$
\left(-\frac{\mathrm{d} C_{\mathrm{P}}}{\mathrm{d} t}\right)=\left(-\frac{\mathrm{d} C_{\mathrm{P}}}{\mathrm{d} t}\right)_{\mathrm{disp}}+\left(-\frac{\mathrm{d} C_{\mathrm{P}}}{\mathrm{d} t}\right)_{\mathrm{ads}}+\left(-\frac{\mathrm{d} F_{\mathrm{P}}}{\mathrm{d} V}\right)_{\mathrm{ox}}{ }^{\prime}
$$

To determine the evolution of phenol oxidation with reaction time and reactor position during a continuous catalytic ozonation process (Ad/Ox) on a GAC bed, for a $\mathrm{d} L$ volume it was obtained the following Equation (23):

$$
v \times \frac{\partial C_{\mathrm{P}}}{\partial L}-D_{\mathrm{L}} \times \frac{\partial^{2} C_{\mathrm{P}}}{\partial L^{2}}+\frac{\partial C_{\mathrm{P}}}{\partial t}+\left(\frac{1-\varepsilon}{\varepsilon}\right) \times \frac{\partial Z_{\mathrm{P}}}{\partial t}+k_{\mathrm{P}} \times C_{\mathrm{P}}^{n}=0,
$$

where $\varepsilon$ is the bed porosity, $k_{\mathrm{P}}$ is the kinetic constant that relates the reaction of ozone to the phenol in both the liquid and the solid, and $n$ is the kinetic order reaction. Considering that the chemical reaction takes place both in the liquid and at the surface of the GAC, it have been obtained the following Equation (24) from Equations (17) and (18):

$$
-r_{\mathrm{O}_{3}}=k_{\mathrm{c}, \mathrm{L}} \times C_{\mathrm{O}_{3}, \mathrm{~L}} \times C_{\mathrm{P}}+k_{\mathrm{c}, \mathrm{S}} \times \frac{C_{\mathrm{O}_{3}, \mathrm{~L}}}{m} \times Z_{\mathrm{P}}=k_{\mathrm{c}, \mathrm{L}} \times C_{\mathrm{O}_{3}, \mathrm{~L}} \times C_{\mathrm{P}}+k_{\mathrm{c}, \mathrm{S}} \times \frac{C_{\mathrm{O}_{3}, \mathrm{~L}}}{m} \times M_{\mathrm{CAT}}^{2} \times K_{\mathrm{F}} \times C_{\mathrm{P}}^{1 / n_{\mathrm{F}}}
$$

Assuming that the ozone concentration is constant after an initial transitory period, and that the ozone distribution in the liquid and solid is proportional to its consumption [17,37], the following global kinetic constants, $k_{1}$ and $k_{2}$, were defined, which incorporated the chemical reaction and mass transfer, leading to the following expression:

$$
v \times \frac{\partial C_{\mathrm{O}_{3}, \mathrm{~L}}}{\partial L}-D_{\mathrm{L}} \times \frac{\partial^{2} C_{\mathrm{P}}}{\partial L^{2}}+\frac{\partial C_{\mathrm{O}_{3}, \mathrm{~L}}}{\partial t}+k_{1} \times C_{\mathrm{P}}+k_{2} \times C_{\mathrm{P}}^{1 / n_{\mathrm{F}}}=0,
$$

where $k_{1}$ and $k_{2}$ are the kinetic constants of phenol removal, referring to the liquid and solid phases, respectively. The combination of Equations (19)-(21) and (25) offers a description of the evolution of the phenol concentration in the system through the determination of the kinetic, fluodynamic, and equilibrium parameters. 


\subsection{Determination of the Characteristic Parameters of the Continuous Ad/Ox System}

Due to the high complexity of the three-phase Ad/Ox model, before solving the equations describing the process, it was necessary to determine the characteristic parameters of the system. The characteristic parameters it have been considered the interstitial velocity, dispersion coefficient, kinetic constants of adsorption and equilibrium parameters.

The interstitial velocity was determined from the velocity at which the liquid flows through the voids in the bed, according to Equation (26):

$$
v=\frac{Q_{\mathrm{L}}}{A \times \varepsilon}
$$

where $Q_{\mathrm{L}}$ is the liquid flow rate through the bed voids and $A$ is the cross-sectional area of the reactor. With the studied flow rate $\left(Q_{\mathrm{L}}=12 \mathrm{~mL} \mathrm{~min}^{-1}\right)$ and void fraction $(\varepsilon=0.32)$, an interstitial velocity of $5.8 \mathrm{~cm} \mathrm{~min}^{-1}$ was obtained. Another characteristic parameter was the axial dispersion coefficient, which characterises the degree of back-mixing of the flow. For a flow rate $Q_{\mathrm{G}}=0.2 \mathrm{~mL} \mathrm{~min}{ }^{-1}$, a dispersion coefficient $D_{\mathrm{L}}=12.8 \mathrm{~cm}^{2} \mathrm{~min}^{-1}$ was obtained.

Regarding the residence time, the ratio of liquid and gas volumes was considered to be proportional to their respective flow rates. Consequently, both liquid and gas take the same time to circulate through the GAC fixed-bed column. For the studied flow rate, an empty bed contact time (EBCT) of 11.6 min was estimated. This value coincided with the time commonly used (10-30 $\mathrm{min}$ ) in industrial water treatment processes in real plants [38].

With respect to the determination of the mass transfer coefficient of the reaction system $\left(K_{\mathrm{L}} a\right)$ was estimated from ozone concentration in the gas (see Figure S1) for each pressure and ozone flow rate with a determination coefficient of $R^{2} \cong 0.99$ (see Figures S2 and S3). It was observed that with increasing gas flow rate, the mass transfer coefficient increased slightly from 0.130 to $0.183 \mathrm{~min}^{-1}$ at a flow rate of 0.05 and $0.4 \mathrm{~L} \mathrm{~h}^{-1}$ respectively. Regarding the pressure it was observed an increased from 0.110 to $0.125 \mathrm{~min}^{-1}$ at a pressure of 1.0 and $2.5 \mathrm{~atm}$ respectively. Obtained $K_{\mathrm{L}} a$ values were according with other ozonation systems of literature [24,27].

Finally, it have been discussed the equilibrium and kinetic adsorption parameters necessary for the resolution of Equations (19)-(21) and (25). The adsorptive characteristics of the GAC at different pH conditions between 3.0 and 11.0 are shown in Figure 2.

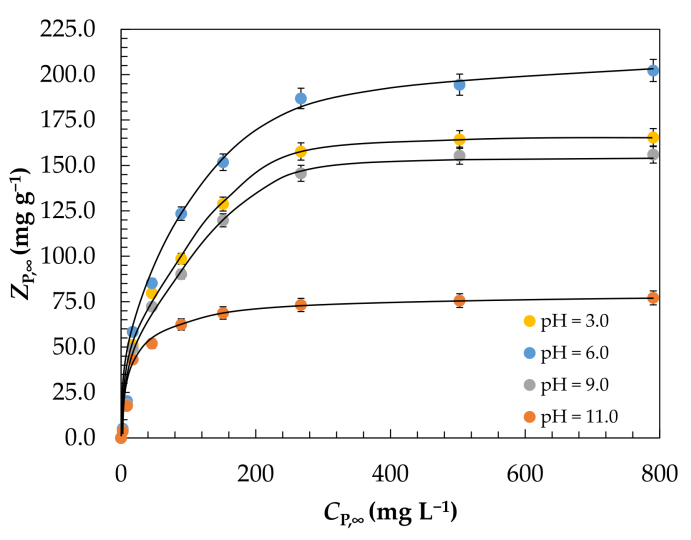

(a)

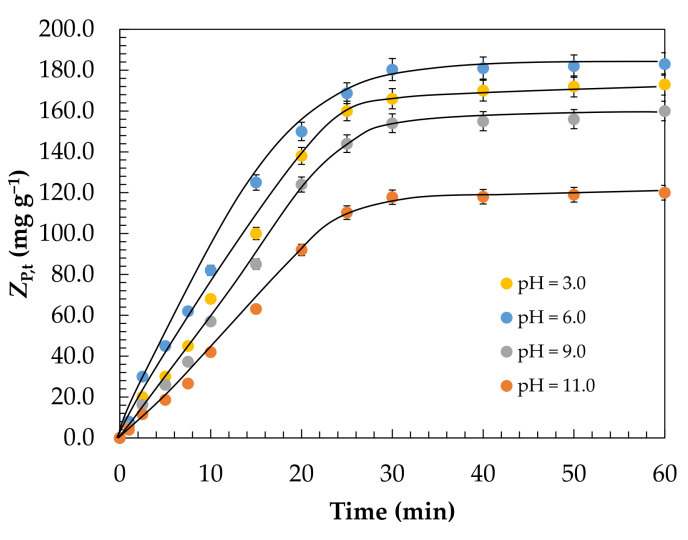

(b)

Figure 2. Determination of the adsorption parameters for the different $\mathrm{pH}$ values studied and at a temperature of $20{ }^{\circ} \mathrm{C}$. (a) Adsorption isotherms of phenol on GAC; (b) evolution of adsorption kinetics fitted to a pseudo-second order model for different hydraulic retention times.

All phenol adsorption isotherms in Figure 2a were fitted by the empirical Freundlich multilayer adsorption model, which assumes the existence of interactions between the adsorbed molecules on the adsorbent [39]. Figure $2 \mathrm{~b}$ shows the adsorption kinetic profiles 
fitted to a pseudo-second order model, which assumes that the chemical reaction is significant. The adsorption parameters necessary to the Ad/Ox kinetic model were listed in Table 1. A regression analysis of the experimental data showed a coefficient of determination $R^{2}>0.98$, indicating that both the Freundlich isotherm and the pseudo-second-order kinetic model adequately described the adsorption phenomena. The amount of phenol adsorbed on the GAC surface was greater $\left(K_{\mathrm{F}}=2.01\left(\mathrm{mg} \mathrm{g}^{-1}\right)\left(\mathrm{L} \mathrm{mg}^{-1}\right)^{1 / n} \mathrm{~F}\right)$ at neutral $\mathrm{pH}$ than that at an alkaline $\mathrm{pH}\left(K_{\mathrm{F}}=1.49\left(\mathrm{mg} \mathrm{g}^{-1}\right)\left(\mathrm{L} \mathrm{mg}^{-1}\right)^{1 / n} \mathrm{~F}\right)$. This could be because when the $\mathrm{pH}$ of the solution is higher, the electrostatic interactions of attraction between the phenol and the GAC are lower [40].

Table 1. Summary of the kinetic parameters obtained from the pseudo-second-order and equilibrium model determined via the Freundlich isotherm model for the adsorption of phenol on the GAC's surface at a temperature of $20^{\circ} \mathrm{C}$ and different $\mathrm{pH}$ values.

\begin{tabular}{ccccc}
\hline & $\mathbf{p H}=\mathbf{3 . 0}$ & $\mathbf{p H}=\mathbf{6 . 0}$ & $\mathbf{p H}=\mathbf{9 . 0}$ & $\mathbf{p H}=\mathbf{1 1 . 0}$ \\
\hline Equilibrium & \multicolumn{3}{c}{} \\
\hline$K_{\mathrm{F}},\left(\mathrm{mg} \mathrm{g}^{-1}\right)\left(\mathrm{L} \mathrm{mg}^{-1}\right)^{1 / n} \mathrm{~F}$ & 1.89 & 2.01 & 1.82 & 1.49 \\
$n_{\mathrm{F}}$ & 1.12 & 1.19 & 1.10 & 1.06 \\
$R^{2}$ & 0.981 & 0.995 & 0.984 & 0.991 \\
\hline Kinetic $^{-}$ & & \\
\hline$k_{\text {ads }} \mathrm{g} \mathrm{mg}^{-1} \mathrm{~min}^{-1}$ & $2.77 \times 10^{-4}$ & $3.10 \times 10^{-4}$ & $2.52 \times 10^{-4}$ & $4.85 \times 10^{-5}$ \\
$R^{2}$ & 0.992 & 0.987 & 0.996 & 0.993 \\
\hline
\end{tabular}

In order to explain the effect of $\mathrm{pH}$ on the adsorption phenomenon in more detail, the zeta potential was determined over a wide range of $\mathrm{pH}$ (2.5-11.5) (Figure 3). Based on obtained zeta potential values, at $\mathrm{pH}=7.0$, it was observed that the attraction due to electrostatic charge was greater than at other acidic or alkaline $\mathrm{pH}$ values. This is because their potential value $(32.2 \mathrm{mV})$ was higher than that observed at $\mathrm{pH}=3.0(30.53 \mathrm{mV})$ or $\mathrm{pH}=9.0(10.47 \mathrm{mV})$. In contrast, at $\mathrm{pH}=11.0$, a lower adsorption capacity was achieved because of the repulsive forces between the negative charges of the phenol and the GAC surface difficult the adsorption of phenol. For this reason, the zeta potential value was $-2.2 \mathrm{mV}$. Although higher adsorption of phenol would be achieved at neutral or acidic $\mathrm{pH}$, oxidation by catalytic ozonation will be more effective at alkaline $\mathrm{pH}$ values because the generation of more hydroxyl radicals is promoted. Consequently, it will be necessary to work at higher $\mathrm{pH}$ values even if the adsorptive properties of the GAC are lost.

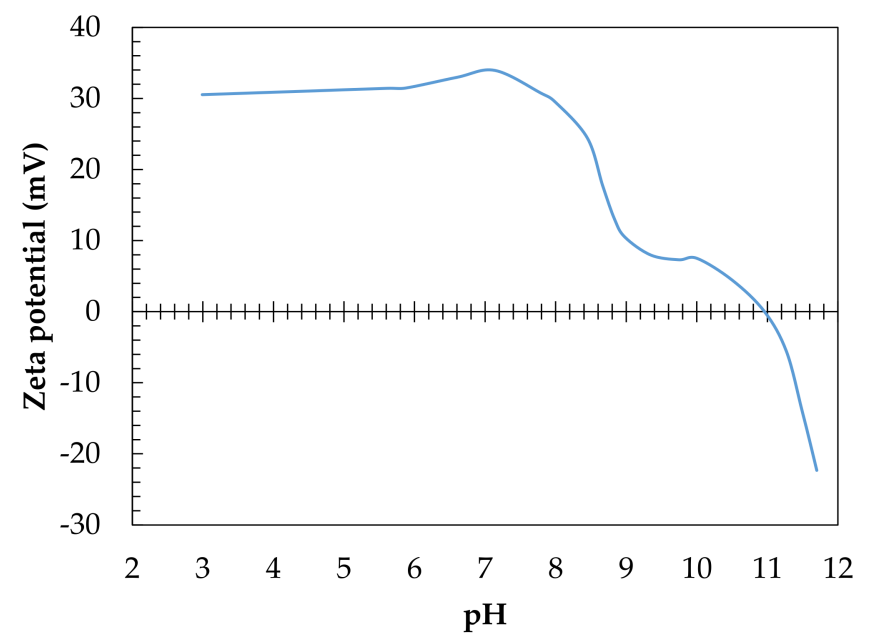

Figure 3. Evolution of the GAC's zeta potential at different $\mathrm{pH}$ values. 


\subsection{Effect of Operational Conditions and Kinetic Model Validation}

In order to establish the most favourable operational conditions leading to higher mineralisation and primary degradation, the effects of system pressure, ozone dose, ozone flow rate, initial phenol concentration, and $\mathrm{pH}$ on the fixed-bed reaction system with GAC were analysed. Figure 4 shows the transient profiles of the obtained primary degradation and mineralization, fitted to the proposed Ad/Ox model.

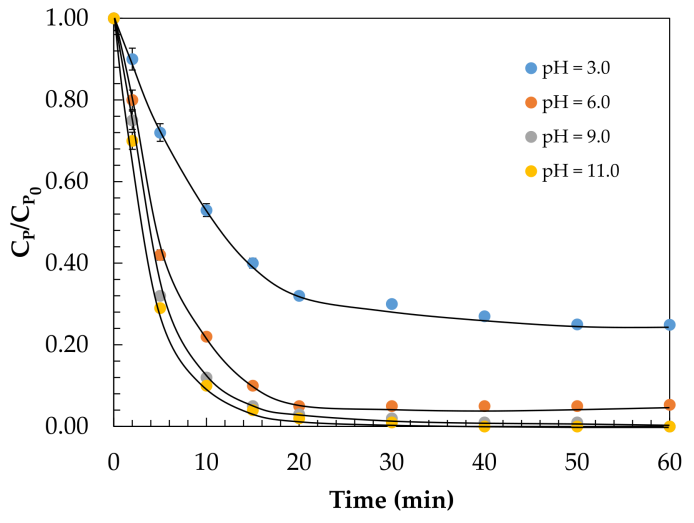

(a)

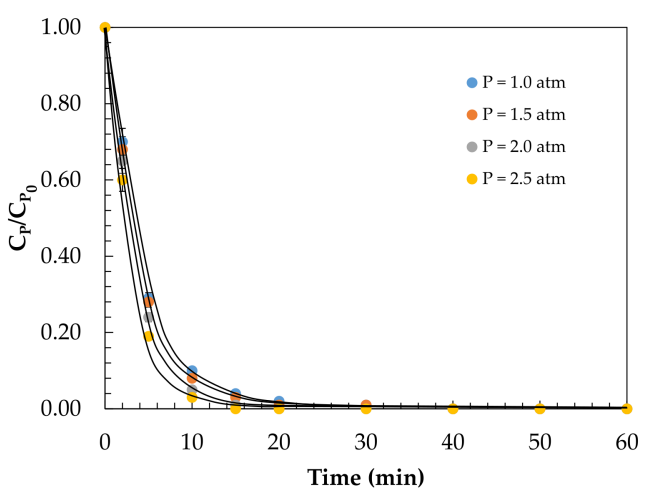

(c)

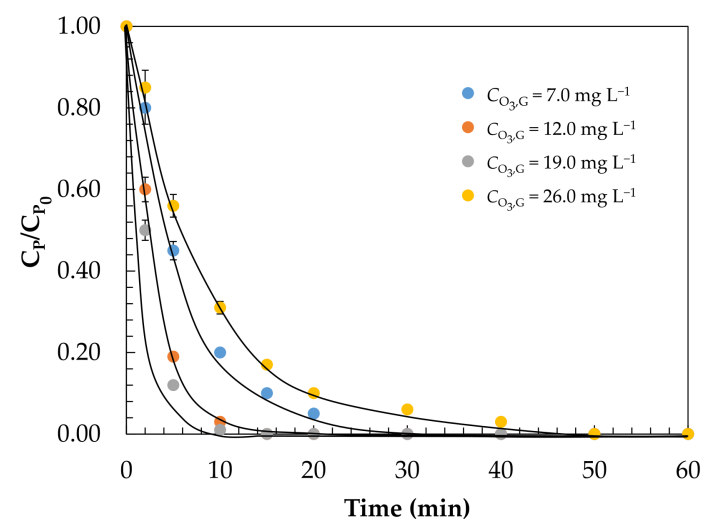

(e)

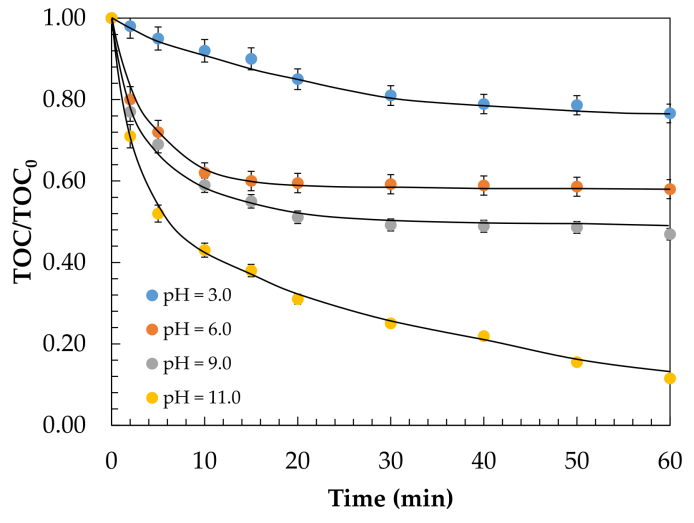

(b)

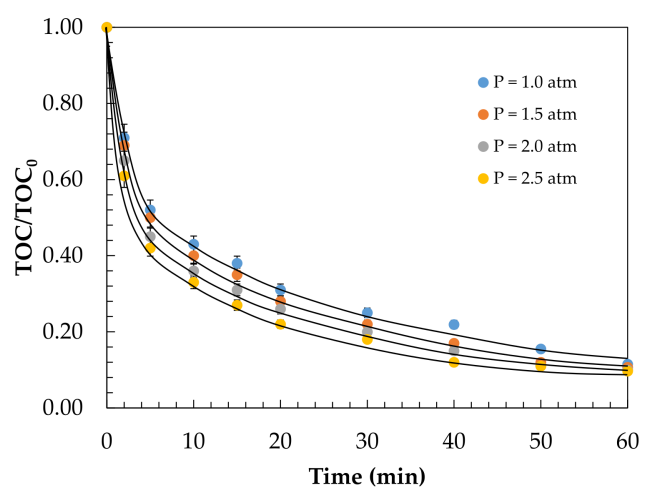

(d)

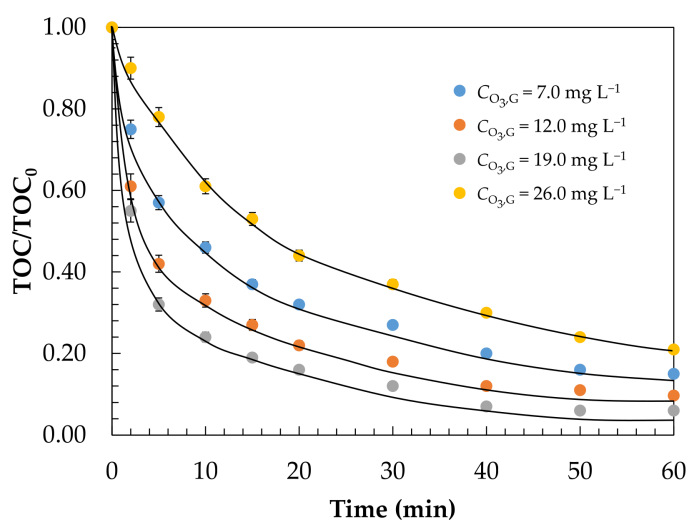

(f)

Figure 4. Effect of operational conditions on the primary degradation and mineralisation of phenol-containing waters during a catalytic ozonation process with GAC: $(\mathbf{a}, \mathbf{b}) \mathrm{pH}^{1},(\mathbf{c}, \mathbf{d})$ pressure ${ }^{2}$, and $(\mathbf{e}, \mathbf{f})$ ozone concentration at inlet ${ }^{3}$, showing the experimental profiles and fitted to the Ad/Ox kinetic model. Experimental conditions: ${ }^{1} C_{\mathrm{P}_{0}}=250.0 \mathrm{mg} \mathrm{L}-1, P=1.0 \mathrm{~atm}$, $C_{\mathrm{O}_{3}, \mathrm{G}}=12.0 \mathrm{mg} \mathrm{L}^{-1}, Q_{\mathrm{L}}=12 \mathrm{~mL} \mathrm{~min}{ }^{-1}, Q_{\mathrm{G}}=0.05 \mathrm{~L} \mathrm{~h}^{-1}, V=0.14 \mathrm{~L} ;{ }^{2} C_{\mathrm{P}_{0}}=250.0 \mathrm{mg} \mathrm{L}-1, \mathrm{pH}^{-1}=11.0$, $C_{\mathrm{O}_{3}, \mathrm{G}}=12.0 \mathrm{mg} \mathrm{L}^{-1}, Q_{\mathrm{L}}=12 \mathrm{~mL} \mathrm{~min}^{-1}, \mathrm{Q}_{\mathrm{G}}=0.05 \mathrm{~L} \mathrm{~h}^{-1}, V=0.14 \mathrm{~L}^{3}{ }^{3} C_{\mathrm{P}_{0}}=250.0 \mathrm{mg} \mathrm{L}^{-1}, P=2.5 \mathrm{~atm}, \mathrm{pH}=11.0$, $Q_{\mathrm{L}}=12 \mathrm{~mL} \mathrm{~min}^{-1}, Q_{\mathrm{G}}=0.05 \mathrm{~L} \mathrm{~h}^{-1}, V=0.14 \mathrm{~L}$. 
According to Figure $4 \mathrm{a}, \mathrm{b}$, the $\mathrm{pH}$ of the solution plays an important role in the catalytic ozonation of phenol, as well as in the mass transfer and its subsequent decomposition [24]. As the $\mathrm{pH}$ of the solution increased, the rate of degradation and mineralisation increased, becoming higher than at more acidic $\mathrm{pH}$. This is because at more alkaline $\mathrm{pH}$, the oxidation mechanism involved is predominantly radicalary and generates more $\mathrm{HO}^{\bullet}$ due to the higher concentration of hydroxide anions, and, consequently, a higher oxidation potential $\left(\mathrm{E}^{\circ}=2.80 \mathrm{~V}\right)[41]$ as shown in Figure S4a. In contrast, at weakly acidic $\mathrm{pH}$ levels, the predominant mechanism is the direct reaction of ozone, as this pathway is more selective [27]. This statement could lead to an error, given that at $\mathrm{pH}=11.0$, the participation of the direct reaction of ozone with phenol is insignificant. This is because depending on the $\mathrm{pH}$, phenol can dissociate, according to the equilibrium shown in Equation (27) [17]:

$$
\mathrm{C}_{6} \mathrm{H}_{5} \mathrm{OH}(\mathrm{aq})+\mathrm{H}_{2} \mathrm{O}(\mathrm{l}) \rightleftarrows \mathrm{C}_{6} \mathrm{H}_{5} \mathrm{O}^{-}(\mathrm{aq})+\mathrm{H}_{3} \mathrm{O}^{+}(\mathrm{aq}) \mathrm{pK}_{\mathrm{a}}=9.95
$$

According to Equation (27), the nature of these species could affect the reactivity with ozone. At acidic $\mathrm{pH}$, electrophilic substitution reactions with ozone (direct reaction) would be promoted due to the character of the substituent groups. However, since the -O- group of phenolate ion is more reactive group $\left(k=1.4 \times 10^{9} \mathrm{M}^{-1} \mathrm{~s}^{-1}\right)$ than $-\mathrm{OH}$ $\left(k=1300 \mathrm{M}^{-1} \mathrm{~s}^{-1}\right)$ of phenol [22], the reactivity of ozone increases with $\mathrm{pH}$ to attack the pollutant. Consequently, at $\mathrm{pH}=11.0$, complete primary degradation and mineralisation was achieved, with a total organic carbon reduction of $88.5 \%$.

This same behaviour was observed by Xiong et al. [33] -in a slurry-type reactor. A mineralisation of $70.2 \%$ was achieved operating at an alkaline $\mathrm{pH}$. Oyher authors such as, Chand et al. [42] observed an increase of $7.2 \%$ in phenol mineralisation operating at a slightly alkaline $\mathrm{pH}(\mathrm{pH}=9.0)$. The difference in efficiency observed could be due to the $\mathrm{pH}$ plays a determining role in the charge of the surface hydroxyl groups on the catalyst. In this respect, the adsorptive properties of the GAC could contribute to the greater adsorption of the degradation by-products, and, consequently, to a greater reduction in TOC. In any case, the contribution of adsorption during the catalytic ozonisation of phenol-containing waters did not comprise more than $5-23 \%$ of the TOC removal [43].

In order to validate the Ad/Ox kinetic model for the proposed continuous catalytic ozonisation process, the dynamics were adjusted for the different operational conditions. In Table 2, the values of the kinetic constants obtained after adjusting the profiles for the analyses of both primary degradation and mineralisation are shown. According to the relative standard error values, in general terms, the fit was good, showing an RSE of approximately $5 \%$ for the primary degradation and mineralisation profiles. According to the kinetic constant $k_{2}$, referring to the solid, slight increases were observed at neutral $\left(4.6 \times 10^{-3}\right.$ $\left.\left(\mathrm{mg} \mathrm{L}^{-1}\right)\left(\mathrm{mg} \mathrm{g}^{-1} \text { GAC min }\right)^{-1}\right)$ and acidic $\left(3.8 \times 10^{-3}\left(\mathrm{mg} \mathrm{L}^{-1}\right)\left(\mathrm{mg} \mathrm{g}^{-1} \text { GAC min }\right)^{-1}\right)$ $\mathrm{pH}$ values, agreeing with the adsorption phenomenon described above. Respect the kinetic constant of the liquid $\left(k_{1}\right)$, at alkaline $\mathrm{pH}\left(k_{1}=0.20 \mathrm{~min}^{-1}\right)$, it was observed in Figure $S 4 a$, an increased production of radical species capable of degrading a phenol-containing effluent. The kinetic constants obtained from the evolution of the mineralisation were lower due to the more refractory nature of the degradation products such as p-benzoquinone $\left(k=2.5 \times 10^{3} \mathrm{M}^{-1} \mathrm{~s}^{-1}\right)$ or catechol $\left(k=5.2 \times 10^{5} \mathrm{M}^{-1} \mathrm{~s}^{-1}\right)$ according with Figure S5 [22]. 
Table 2. Summary of the adsorption and oxidation kinetic constants of the Ad/Ox kinetic model related to the removal and mineralisation of phenol during catalytic ozonation with GAC.

\begin{tabular}{|c|c|c|c|c|}
\hline \multirow{2}{*}{ Parameter/Evolution } & \multicolumn{4}{|c|}{ Effect of $\mathrm{pH}^{1}$} \\
\hline & $\mathrm{pH}=3.0$ & $\mathrm{pH}=6.0$ & $\mathrm{pH}=9.0$ & $\mathrm{pH}=11.0$ \\
\hline \multicolumn{5}{|l|}{ Phenol removal } \\
\hline$k_{1}\left(\min ^{-1}\right)$ & 0.05 & 0.09 & 0.12 & 0.20 \\
\hline$k_{2} \times 10^{3}\left(\mathrm{mg} \mathrm{L}^{-1}\right)\left(\mathrm{mg} \mathrm{g}^{-1} \mathrm{GAC} \min \right)^{-1}$ & 3.8 & 4.6 & 3.7 & 2.1 \\
\hline RSE $(\%)$ & 4.5 & 5.3 & 5.0 & 4.8 \\
\hline \multicolumn{5}{|l|}{ Mineralisation } \\
\hline$k_{1} \times 10^{1}\left(\min ^{-1}\right)$ & 0.009 & 0.017 & 0.022 & 0.038 \\
\hline \multirow{4}{*}{$\begin{array}{c}k_{2} \times 10^{4}\left(\mathrm{mg} \mathrm{L}^{-1}\right)\left(\mathrm{mg} \mathrm{g}^{-1} \mathrm{GAC} \mathrm{min}^{-1}\right. \\
\operatorname{RSE}(\%)\end{array}$} & 0.71 & 0.86 & 0.69 & 0.39 \\
\hline & 3.7 & 4.1 & 3.9 & 4.4 \\
\hline & \multicolumn{4}{|c|}{ Effect of pressure ${ }^{2}$} \\
\hline & $P=1.0 \mathrm{~atm}$ & $P=1.5 \mathrm{~atm}$ & $P=2.0 \mathrm{~atm}$ & $P=2.5 \mathrm{~atm}$ \\
\hline \multicolumn{5}{|l|}{ Phenol removal } \\
\hline$k_{1}\left(\min ^{-1}\right)$ & 0.20 & 0.21 & 0.22 & 0.23 \\
\hline$k_{2} \times 10^{3}\left(\mathrm{mg} \mathrm{L}^{-1}\right)\left(\mathrm{mg} \mathrm{g}^{-1} \mathrm{GAC} \mathrm{min}^{-1}\right.$ & 2.1 & 2.1 & 2.1 & 2.2 \\
\hline RSE (\%) & 4.1 & 4.6 & 4.0 & 5.2 \\
\hline \multicolumn{5}{|l|}{ Mineralisation } \\
\hline$k_{1} \times 10^{1}\left(\mathrm{~min}^{-1}\right)$ & 0.038 & 0.039 & 0.041 & 0.044 \\
\hline$k_{2} \times 10^{4}\left(\mathrm{mg} \mathrm{L}^{-1}\right)\left(\mathrm{mg} \mathrm{g}^{-1} \mathrm{GAC} \min \right)^{-1}$ & 0.39 & 0.39 & 0.39 & 0.42 \\
\hline \multirow[t]{3}{*}{$R S E(\%)$} & 4.5 & 4.2 & 4.7 & 4.3 \\
\hline & \multicolumn{4}{|c|}{ Effect of ozone gas concentration ${ }^{3}$} \\
\hline & $C_{\mathrm{O}_{3}, \mathrm{G}}=7.0 \mathrm{mg} \mathrm{L}^{-1}$ & $C_{\mathrm{O}_{3}, \mathrm{G}}=12.0 \mathrm{mg} \mathrm{L}^{-1}$ & $C_{\mathrm{O}_{3}, \mathrm{G}}=19.0 \mathrm{mg} \mathrm{L}^{-1}$ & $C_{\mathrm{O}_{3}, \mathrm{G}}=26.0 \mathrm{mg} \mathrm{L}^{-1}$ \\
\hline \multicolumn{5}{|l|}{ Phenol removal } \\
\hline$k_{1}\left(\min ^{-1}\right)$ & 0.19 & 0.23 & 0.24 & 0.15 \\
\hline$k_{2} \times 10^{3}\left(\mathrm{mg} \mathrm{L}^{-1}\right)\left(\mathrm{mg} \mathrm{g}^{-1} \mathrm{GAC} \min \right)^{-1}$ & 2.0 & 2.2 & 2.4 & 1.8 \\
\hline$R S E(\%)$ & 5.3 & 4.9 & 4.9 & 5.1 \\
\hline \multicolumn{5}{|l|}{ Mineralisation } \\
\hline$k_{1} \times 10^{1}\left(\min ^{-1}\right)$ & 0.036 & 0.044 & 0.045 & 0.028 \\
\hline \multirow{4}{*}{$k_{2} \times 10^{4}\left(\mathrm{mg} \mathrm{L}^{-1}\right)\left(\mathrm{mg} \mathrm{g}^{-1} \mathrm{GAC} \mathrm{min}^{-1}\right.$} & 0.37 & 0.42 & 0.45 & 0.34 \\
\hline & 4.8 & 4.2 & 4.6 & 4.7 \\
\hline & \multicolumn{4}{|c|}{ Effect of ozone flow rate ${ }^{4}$} \\
\hline & $Q_{\mathrm{G}}=0.05 \mathrm{~L} \mathrm{~h}^{-1}$ & $Q_{\mathrm{G}}=0.1 \mathrm{~L} \mathrm{~h}^{-1}$ & $Q_{\mathrm{G}}=0.2 \mathrm{~L} \mathrm{~h}^{-1}$ & $Q_{\mathrm{G}}=0.4 \mathrm{~L} \mathrm{~h}^{-1}$ \\
\hline \multicolumn{5}{|l|}{ Phenol removal } \\
\hline$k_{1}\left(\min ^{-1}\right)$ & 0.24 & 0.25 & 0.26 & 0.27 \\
\hline$k_{2} \times 10^{3}\left(\mathrm{mg} \mathrm{L}^{-1}\right)\left(\mathrm{mg} \mathrm{g}^{-1} \mathrm{GAC} \min \right)^{-1}$ & 2.4 & 2.4 & 2.5 & 2.5 \\
\hline RSE $(\%)$ & 4.7 & 4.9 & 4.4 & 4.2 \\
\hline \multicolumn{5}{|l|}{ Mineralisation } \\
\hline$k_{1} \times 10^{1}\left(\mathrm{~min}^{-1}\right)$ & 0.045 & 0.047 & 0.049 & 0.051 \\
\hline \multirow{4}{*}{$k_{2} \times 10^{4}\left(\mathrm{mg} \mathrm{L}^{-1}\right)\left(\mathrm{mg} \mathrm{g}^{-1} \mathrm{GAC} \mathrm{min}^{-1}\right.$} & 0.45 & 0.45 & 0.47 & 0.47 \\
\hline & 5.0 & 4.4 & 4.8 & 4.3 \\
\hline & \multicolumn{4}{|c|}{ Effect of initial phenol concentration ${ }^{5}$} \\
\hline & $C_{\mathrm{P}_{0}}=250.0 \mathrm{mg} \mathrm{L}^{-1}$ & $C_{\mathrm{P}_{0}}=500.0 \mathrm{mg} \mathrm{L}^{-1}$ & $C_{\mathrm{P}_{0}}=750.0 \mathrm{mg} \mathrm{L}^{-1}$ & $C_{\mathrm{P}_{0}}=1000.0 \mathrm{mg} \mathrm{L}^{-1}$ \\
\hline \multicolumn{5}{|l|}{ Phenol removal } \\
\hline$k_{1}\left(\min ^{-1}\right)$ & 0.27 & 0.19 & 0.17 & 0.16 \\
\hline$k_{2} \times 10^{3}\left(\mathrm{mg} \mathrm{L}^{-1}\right)\left(\mathrm{mg} \mathrm{g}^{-1} \mathrm{GAC} \mathrm{min}^{-1}\right.$ & 2.5 & 2.7 & 3.0 & 3.2 \\
\hline RSE $(\%)$ & 4.0 & 4.3 & 4.8 & 4.5 \\
\hline \multicolumn{5}{|l|}{ Mineralisation } \\
\hline$k_{1} \times 10^{1}\left(\mathrm{~min}^{-1}\right)$ & 0.051 & 0.036 & 0.031 & 0.030 \\
\hline$k_{2} \times 10^{4}\left(\mathrm{mg} \mathrm{L}^{-1}\right)\left(\mathrm{mg} \mathrm{g}^{-1} \mathrm{GAC} \mathrm{min}^{-1}\right.$ & 0.47 & 0.51 & 0.56 & 0.60 \\
\hline$R S E(\%)$ & 4.2 & 4.6 & 3.9 & 4.4 \\
\hline
\end{tabular}

Experimental conditions: ${ }^{1} C_{\mathrm{P}_{0}}=250.0 \mathrm{mg} \mathrm{L}^{-1}, P=1.0 \mathrm{~atm}, C_{\mathrm{O}_{3}, \mathrm{G}}=12.0 \mathrm{mg} \mathrm{L}^{-1}, Q_{\mathrm{L}}=12 \mathrm{~mL} \mathrm{~min}^{-1}, Q_{\mathrm{G}}=0.05 \mathrm{~L} \mathrm{~h}{ }^{-1}, V=0.14 \mathrm{~L}$.

${ }^{2} C_{\mathrm{P}_{0}}=250.0 \mathrm{mg} \mathrm{L}^{-1}, \mathrm{pH}=11.0, C_{\mathrm{O}_{3}, \mathrm{G}}=12.0 \mathrm{mg} \mathrm{L}^{-1}, Q_{\mathrm{L}}=12 \mathrm{~mL} \mathrm{~min}^{-1}, Q_{\mathrm{G}}=0.05 \mathrm{~L} \mathrm{~h}^{-1}, V=0.14 \mathrm{~L} .{ }^{3} C_{\mathrm{P}_{0}}=250.0 \mathrm{mg} \mathrm{L}^{-1}, P=2.5 \mathrm{~atm}$, $\mathrm{pH}=11.0, Q_{\mathrm{L}}=12 \mathrm{~mL} \mathrm{~min}^{-1}, Q_{\mathrm{G}}=0.05 \mathrm{~L} \mathrm{~h}^{-1}, V=0.14 \mathrm{~L} .{ }^{4} C_{\mathrm{P} 0}=250.0 \mathrm{mg} \mathrm{L}^{-1}, P=2.5 \mathrm{~atm}, \mathrm{pH}=11.0 ; C_{\mathrm{O}_{3}, \mathrm{G}}=19.0 \mathrm{mg} \mathrm{L}^{-1}$, $Q_{\mathrm{L}}=12 \mathrm{~mL} \mathrm{~min}^{-1}, V=0.14 \mathrm{~L} .{ }^{5} \mathrm{pH}=11.0, P=2.5 \mathrm{~atm} ; C_{\mathrm{O}_{3}, \mathrm{G}}=19.0 \mathrm{mg} \mathrm{L}^{-1}, Q_{\mathrm{L}}=12 \mathrm{~mL} \mathrm{~min}^{-1}, Q_{\mathrm{G}}=0.4 \mathrm{~L} \mathrm{~h}^{-1}, V=0.14 \mathrm{~L}$.

The effect of system pressure on the enhancement of degradation and mineralisation was studied in the range of 1 to $2.5 \mathrm{~atm}$. Pressure is a operational variable that could affect mass transfer and, consequently, improve the contact amongst the ozone molecules in the gaseous and liquid phases [44,45] (see Figure S2). As shown in Figure 4c,d, the increase in pressure to $2.5 \mathrm{~atm}$ had a slightly positive effect, but not as evident as the effect of $\mathrm{pH}$, 
because it only improved mineralisation by $1.8 \%$, which was within the experimental error. The observed improvement could be due to the generation of slightly smaller bubbles, which could lead to an increase in the specific contact surface area between the liquid and gas phases. The same effect was observed for the kinetic constants of the Ad/Ox model. This could be due to the internal pressure in the gas microbubbles being much higher than the external pressure applied to them.

Figure $4 \mathrm{e}, \mathrm{f}$ show the effects of ozone dose. Increasing the ozone dose from 7.0 to $19.0 \mathrm{mg} \mathrm{L}^{-1}$ increased the force gradient, thus improving the mass transfer and ultimately significantly increasing the rate of phenol removal until complete degradation; subsequently, mineralisation improved from $85.0 \%$ to $94.0 \%$ after reaching a steady state at $60 \mathrm{~min}$. However, higher ozone doses led to a decrease in mineralisation from $94.0 \%$ to $79.0 \%$ at $26.0 \mathrm{mg} \mathrm{L}^{-1}$. This can be explained via the mechanism proposed by Buhler et al. [46], as shown in Equations (28) and (29):

$$
\begin{gathered}
\mathrm{O}_{3}+\mathrm{HO}^{\bullet} \rightarrow \mathrm{HO}_{4}^{\bullet} \quad k=2 \times 10^{9} \mathrm{M}^{-1} \mathrm{~s}^{-1} \\
\mathrm{HO}_{4}^{\bullet} \rightarrow \mathrm{HO}_{2}^{\bullet}+\mathrm{O}_{2} \quad k=2.8 \times 10^{4} \mathrm{~s}^{-1}
\end{gathered}
$$

According to Equations (27) and (28), when there is an ozone dose above the critical value of $19.0 \mathrm{mg} \mathrm{L}^{-1}$, ozone reacts with the generated hydroxyl radicals, producing radicals with a lower oxidative capacity $\left(\mathrm{HO}_{2} \bullet\right.$ and $\left.\mathrm{O}_{2}\right)$ than hydroxyl radical, according with Figure S4b. On the other hand, according to Rekhate and Srivastava [41], another feasible explanation could be that, when applying an excessive ozone dose, its utilisation is limited by the number of active sites available on the GAC catalyst's surface. Consequently, the resulting excess of ozone would react only through the direct pathway.

This same effect was observed by Nawaz et al. [47] who reported TOC removal rates of $50.6,85.2$, and $79.5 \%$ at ozone doses of 10,20 and $50 \mathrm{mg} \mathrm{L}^{-1}$, respectively. However, increasing the ozone dose did not lead to total phenol mineralisation.

After analysing the kinetic constants of the degradation and mineralisation profiles, the use of dose of $19.0 \mathrm{mg} \mathrm{L}^{-1}$ enhanced the kinetics at the solid level $\left(k_{2}=2.4 \times 10^{-3}\right.$ $\left.\left(\mathrm{mg} \mathrm{L}^{-1}\right)\left(\mathrm{mg} \mathrm{g}^{-1} \mathrm{GAC} \mathrm{min}\right)^{-1}\right)$ compared with lower doses $\left(C_{\mathrm{O}_{3}, \mathrm{G}}=7.0 \mathrm{mg} \mathrm{L}^{-1}\right)$, where a constant of $2.0 \times 10^{-3}\left(\mathrm{mg} \mathrm{L}^{-1}\right)\left(\mathrm{mg} \mathrm{g}^{-1} \mathrm{GAC} \min \right)^{-1}$ was obtained. This could have been because the pore structure of the activated carbon may have been affected by the ozonisation treatment, as described by Guelli Ulson de Souza et al. [6] and confirmed in previous studies with pristine and $\mathrm{TiO}_{2}$-doped GACs [17,24].

Another operational variable that could have an effect on phenol removal is the ozone flow rate. Different flow rates between 0.05 and $0.4 \mathrm{~L} \mathrm{~h}^{-1}$ were evaluated (Figure $5 \mathrm{a}, \mathrm{b}$ ). Increasing the ozone flow rate led to a increase in phenol degradation rate and mineralisation efficiency $(97.0 \%)$ at a flow rate of $0.4 \mathrm{~L} \mathrm{~h}^{-1}$. This increase could be due to the influence of the flow rate on the ozone mass transfer from the gas to the liquid phase (see Figure S3), and therefore on the effective ozone utilisation. This effect was negligible; a better explanation might be that the quantity of ozone transferred to the liquid phase was higher than that used for oxidation and subsequent decomposition. As was the case with pressure, the improvement in the kinetic constants was not clearly evident here, except the one for the oxidation in the liquid $\left(k_{1}\right)$, which increased from 0.045 to $0.051 \mathrm{~min}^{-1}$ in the mineralisation. 


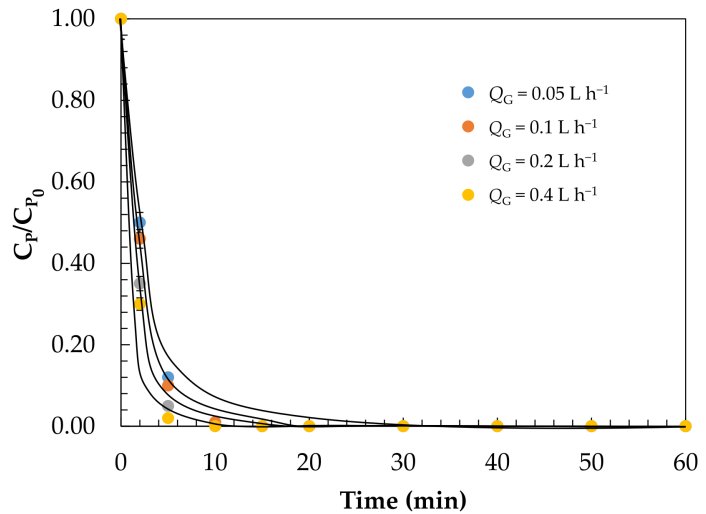

(a)

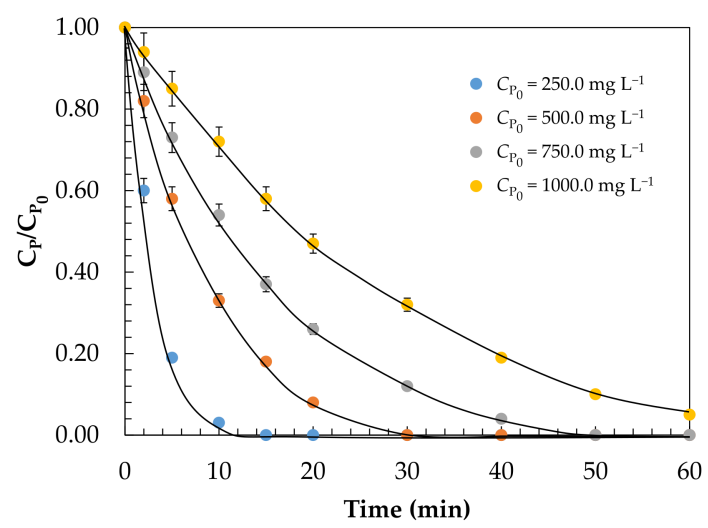

(c)

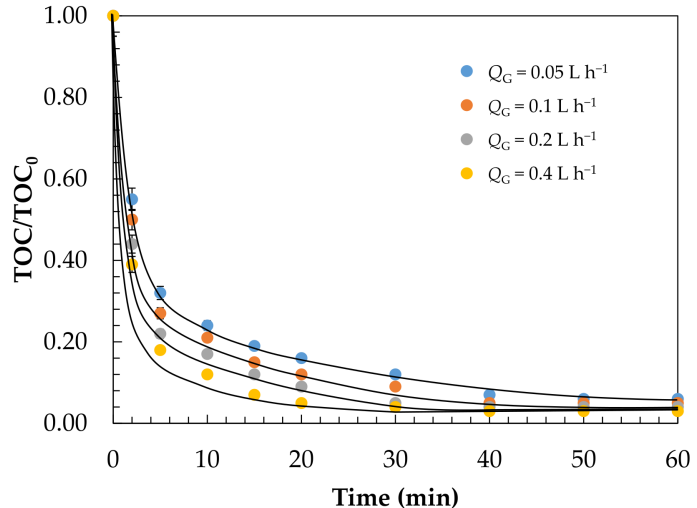

(b)

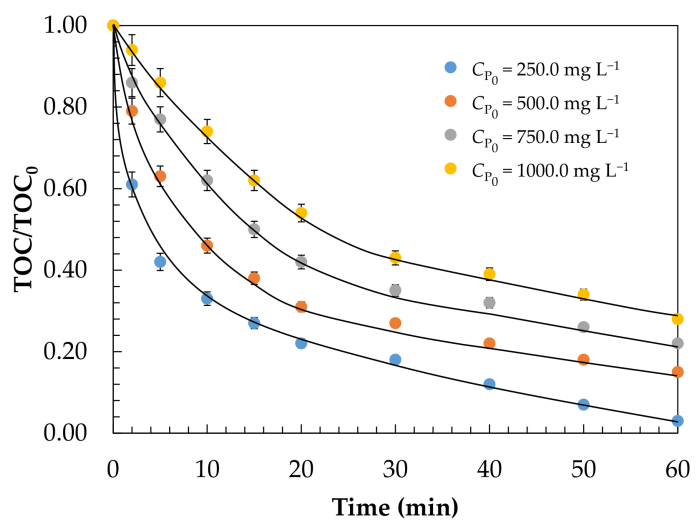

(d)

Figure 5. Analysis of $C_{P}$ and TOC concentration profiles during the initial transitory period $(\mathrm{t}<70 \mathrm{~min})$ and adjustment to the Ad/Ox kinetic model. Effect of $(\mathbf{a}, \mathbf{b})$ ozone flow rate ${ }^{1}$ and $(\mathbf{c}, \mathbf{d})$ concentration of the pollutant load ${ }^{2}$. Experimental conditions: ${ }^{1} C_{\mathrm{P}_{0}}=250.0 \mathrm{mg} \mathrm{L}^{-1}, P=2.5 \mathrm{~atm}, \mathrm{pH}=11.0 ; C_{\mathrm{O}_{3}, \mathrm{G}}=19.0 \mathrm{mg} \mathrm{L}^{-1}, Q_{\mathrm{L}}=12 \mathrm{~mL} \mathrm{~min}^{-1}, V=0.14 \mathrm{~L}$; $2 \mathrm{pH}=11.0, P=2.5 \mathrm{~atm} ; C_{\mathrm{O}_{3}, \mathrm{G}}=19.0 \mathrm{mg} \mathrm{L}^{-1}, Q_{\mathrm{L}}=12 \mathrm{~mL} \mathrm{~min}^{-1}, Q_{\mathrm{G}}=0.05 \mathrm{~L} \mathrm{~h}^{-1}, V=0.14 \mathrm{~L}$.

This same effect was observed by Yang et al. [48] during the treatment of an industrial effluent. A significant reduction in COD was initially observed up to a critical value of $2.0 \mathrm{~L} \mathrm{~min}^{-1}$. After that, a negative effect was seen.

In order to study the feasibility of the catalytic ozonation treatment in this continuous system, a wider range of initial phenol concentrations that are common in industrial effluents (up to $1000.0 \mathrm{mg} \mathrm{L}^{-1}$ ) was evaluated [17]. As shown in Figure $5 \mathrm{c}$,d, the time required for complete degradation and TOC removal was greater at higher initial phenol concentrations [49]. Evaluating the transitory profiles, it can be seen that after $70 \mathrm{~min}$ of reaction, the same levels of complete degradation and $97.0 \%$ mineralisation were reached, and kinetic constants for the initial concentration of $1000.0 \mathrm{mg} \mathrm{L}^{-1}$ of $0.27 \mathrm{~min}^{-1}$ and $2.5 \times 10^{-3}\left(\mathrm{mg} \mathrm{L}^{-1}\right)\left(\mathrm{mg} \mathrm{g}^{-1} \mathrm{GAC} \mathrm{min}\right)^{-1}$ were obtained.

As a comparison of the obtained efficiencies, Lin and Wang [50] studied the removal of phenol through a catalytic ozonation process in a basket reactor with $\mathrm{AC}$ as the catalyst. At a temperature of $30^{\circ} \mathrm{C}$ and after $2 \mathrm{~h}$ of reaction, they achieved complete phenol removal and a COD reduction rate of $85 \%$. Beltrán et al. [43] evaluated the use of AC catalysts with other oxides, such as $\mathrm{Fe}, \mathrm{Co}$, and alumina, to treat a phenol-containing effluent via catalytic ozonation in a slurry reactor. However, no significant improvement was observed in the catalytic activities of the AC and the other three composites in terms of TOC reduction, which was about $90 \%$ after $5 \mathrm{~h}$ of reaction. Chaichanawong et al. [39] degraded an aqueous solution containing phenol in a slurry-type reactor, via a catalytic ozonisation process with three ACs with different physico-chemical properties. With a mesoporous carbon, the 
complete degradation of phenol and a mineralisation of $85.7 \%$ were obtained during the ozonisation and simultaneous adsorption process over $2 \mathrm{~h}$. Guelli Ulson de Souza et al. [6] studied the simultaneous application of ozonation and adsorption processes in a packed bed of AC for the removal of phenol from an industrial stream. With a catalyst loading of $592.22 \mathrm{~g} \mathrm{~L}^{-1}$, it achieved complete degradation and a COD reduction of $60.67 \%$.

Finally, the toxicity of the effluent was determined in order to evaluate the feasibility of the discharge of the treated effluent into the river. According to De Luis et al. [16], a toxicity value less than $1 \mathrm{TU}$ indicates that an effluent is non-toxic or exhibits low toxicity. Thus, the effluent before treatment showed a value of $18.02 \mathrm{TU}$, while after treatment carried out under favourable operational conditions its toxicity decreased to $0.09 \mathrm{TU}$.

In overall terms, taking into account that complete degradation, a mineralisation of $97.0 \%$ and a toxicity-free effluent were obtained with an empty bed contact time of $11.6 \mathrm{~min}$ and a catalyst load of $432.14 \mathrm{~g} \mathrm{~L}^{-1}$. The adequately combine adsorption and ozonisation processes shows that the proposed continuous Ad/Ox system would be viable for scaling up into a real process in accordance with the technical criteria.

\section{Materials and Methods}

\subsection{Materials}

The granular activated carbon Kemisorb ${ }^{\circledR} 530$ GR $12 \times 40$ (Kemira Ibérica, Barcelona, Spain) was used as the catalytic material, with an average particle size of $1.0 \mathrm{~mm}$. The activated carbon used throughout the experiments was characterised in a previous work [17]. Table 3 summarises the main physical properties of the GAC Kemisorb ${ }^{\circledR} 530$.

Table 3. Textural and chemical surface properties of GAC Kemisorb ${ }^{\circledR} 530$.

\begin{tabular}{cc}
\hline Property & Kemisorb $^{\circledR} \mathbf{5 3 0}$ \\
\hline $\mathrm{S}_{\mathrm{BET}}\left(\mathrm{m}^{2} \mathrm{~g}^{-1}\right)$ & 961.5 \\
$\mathrm{~S}_{\text {ext }}\left(\mathrm{m}^{2} \mathrm{~g}^{-1}\right)$ & 410.4 \\
$\mathrm{~V}_{\mathrm{T}}\left(\mathrm{cm}^{3} \mathrm{~g}^{-1}\right)$ & 0.38 \\
$\mathrm{~V}_{\text {micro }}\left(\mathrm{cm}^{3} \mathrm{~g}^{-1}\right)$ & 0.24 \\
$\mathrm{~V}_{\text {meso }}\left(\mathrm{cm}^{3} \mathrm{~g}^{-1}\right)$ & 0.14 \\
$\mathrm{~V}_{\text {meso }} / \mathrm{V}_{\mathrm{T}}(\%)$ & 36.8 \\
$\mathrm{~V}_{\text {micro }} / \mathrm{V}_{\mathrm{T}}(\%)$ & 63.2 \\
$\mathrm{D}_{\mathrm{P}}(\AA)$ & 27.9 \\
$\mathrm{pH} \mathrm{pzc}_{\mathrm{pzc}}$ & 10.95 \\
Ash $(\%)$ & 11.99 \\
Apparent density $\left(\mathrm{kg} \mathrm{m}^{-3}\right)$ & 432.1 \\
\hline
\end{tabular}

S mesopore volume; $\mathrm{V}_{\text {meso }} / \mathrm{V}_{\mathrm{T}} \times 100$-mesopore percentage; $\mathrm{V}_{\text {micro }} / \mathrm{V}_{\mathrm{T}} \times 100$-micropore percentage; $\mathrm{D}_{\mathrm{P}}$ average pore diameter.

The specific surface area $\left(\mathrm{S}_{\mathrm{BET}}\right)$, total $\left(\mathrm{V}_{\mathrm{T}}\right)$, mesopore $\left(\mathrm{V}_{\text {meso }}\right)$ and micropore $\left(\mathrm{V}_{\text {micro }}\right)$ volumes, and the average pore diameter $\left(\mathrm{D}_{\mathrm{p}}\right)$ were obtained using the $\mathrm{BJH}$ model by observing $\mathrm{N}_{2}$ adsorption-desorption isotherms at $77 \mathrm{~K}$ [51]. The point of zero charge $\left(\mathrm{pH}_{\mathrm{pzc}}\right)$ was determined via electrokinetic zeta potential ( () measurements [52]. The composition of GAC Kemisorb $^{\circledR} 530$ was measured using X-ray fluorescence (XRF) [24]. The XRF results indicate that GAC is mainly composed of $\mathrm{SiO}_{2}(7.72 \%)$ and $\mathrm{Al}_{2} \mathrm{O}_{3}(2.64 \%)$, followed by $\mathrm{Fe}_{2} \mathrm{O}_{3}(0.40 \%), \mathrm{CaO}(0.33 \%), \mathrm{SO}_{3}(0.19 \%), \mathrm{MgO}(0.07 \%), \mathrm{Na}_{2} \mathrm{O}(0.06 \%), \mathrm{K}_{2} \mathrm{O}$ $(0.04 \%), \mathrm{P}_{2} \mathrm{O}_{5}(0.09 \%), \mathrm{TiO}_{2}(0.11 \%)$, and $\mathrm{MnO}(0.001 \%)$.

\subsection{Analytical Methods}

Phenol concentration and primary intermediates was measured using a Waters Alliance 2695 high-performance liquid chromatograph system (Waters, Milford, CT, USA) equipped with a Teknokroma Mediterranea SEA C18 threaded column $(150 \mathrm{~mm} \times 4.6 \mathrm{~mm}$, $1.8 \mu \mathrm{m}$, Teknokroma Analitica, Sant Cugat del Vallès, Barcelona, Spain) and a guard column working at $20^{\circ} \mathrm{C}$ under isocratic elution of a water/methanol mixture $(60: 40 \mathrm{v} / \mathrm{v})$ containing acetic acid (1\%), and a flow rate of $1 \mathrm{~mL} \mathrm{~min}^{-1}$ was used. A Waters $2487 \mathrm{UV} /$ Vis 
detector was used at a wavelength of $220 \mathrm{~nm}$ for phenol, hydroquinone, catechol, oxalic acid, formic acid and at $254 \mathrm{~nm}$ for $p$-benzoquinone [53].

The degree of mineralisation was quantified by total organic carbon (TOC) analysis on a Shimadzu TOC-VSCH analyser (Izasa Scientific, Alcobendas, Spain). Toxicity was evaluated in duplicate using the Microtox ${ }^{\circledR}$ bioassay in a Microtox ${ }^{\circledR}$ toxicity analyser, Azur 500 model (Microbics Corp., New Castle, DE, USA). The measurements were carried out according to ISO 11348-3 (1998), "Water Quality-Determination of the inhibitory effect of water samples on the light emission of Aliivibrio fischeri (Luminescent bacteria test)—Part 3: Method using freeze-dried bacteria" [54]. The concentration of $\mathrm{I}_{3}{ }^{-}$, proportional to the concentration of oxidising agents such as hydroxyl radicals was measured following the KI dosimetry method described by Alfonso-Muniozguren et al. [55].

Zeta potential measurements were carried out with a ZetaSizer Ultra (Malvern Panalytical, Malvern, UK) for suspensions of $1 \mathrm{~g} \mathrm{~L}^{-1} \mathrm{GAC}$ in distilled water at different $\mathrm{pHs}$.

The composition of the GAC was determined by X-ray fluorescence spectroscopy (XRF). From the pulverised sample, a borate glass bead was prepared by melting in an induction micro furnace, and mixing the flux Spectromelt A12 (Merck KGaA, Darmstadt, Germany) and the sample to a ratio of 20:1. An oxidising agent was added to promote the removal (in the oxidation phase of the process) of all the organic parts of the carbon and the fixation of the inorganic oxides. The chemical analysis of the beads was carried out in a vacuum atmosphere, using an AXIOS model sequential wavelength dispersive X-ray fluorescence spectrometer (WDXRF-Panalytical). The fluorometer was equipped with an $\mathrm{Rh}$ and three detectors (gaseous flux, scintillation, and Xe) (Malvern Panalytical) [24].

\subsection{Experimental Setup in the Continuous Fixed-Bed Catalytic System}

Phenol removal via a continuous Ad/Ox process was carried out in a polyvinyl chloride (PVC) column filled with GAC with a $25 \mathrm{~mm}$ outer diameter, $21.2 \mathrm{~mm}$ inner diameter and $40 \mathrm{~cm}$ length (Figure 6). The single ozonation and Ad/Ox experiments were performed at a constant ozone flow rate $\left(Q_{\mathrm{G}}=0.05 \mathrm{~L} \mathrm{~h}^{-1}\right)$ and a temperature of $20^{\circ} \mathrm{C}$, with a fresh GAC bed of $60.5 \mathrm{~g}$ for each experiment and a dissolution pumping rate of $Q_{\mathrm{L}}=12 \mathrm{~mL} \mathrm{~min}^{-1}$. The $\mathrm{pH}$ was measured at different initial values (between 3.0 and 11.0), initial phenol concentrations $\left(250,500,750\right.$, and $\left.1000 \mathrm{mg} \mathrm{L}^{-1}\right)$, and a pressure between 1.0 and $2.5 \mathrm{~atm}$ (depending on the experiment).

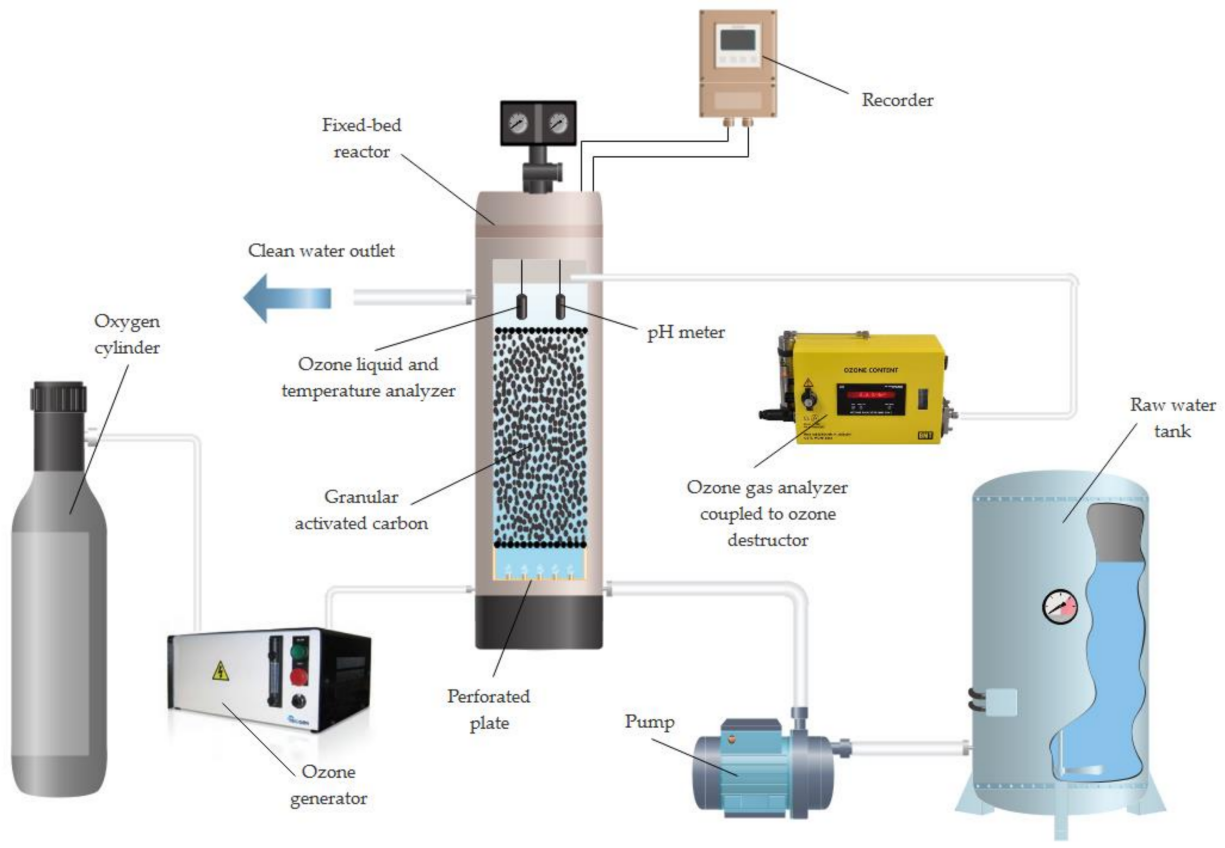

Figure 6. Experimental setup used to carry out ozonation and Ad/Ox tests. 
A typical Ad/Ox or simple ozonisation experiment consisted of a continuous introduction of ozone generated in situ from ultrapure oxygen using a TRIOGEN LAB2B ozone generator (BIO UV, Lunel, France) through a porous plate placed at the bottom of the bed column. Here, the liquid flow of the phenol-containing solution was introduced through a PRECIFLOW peristaltic pump (LAMBDA Laboratory Instruments, Baar, Switzerland), through the lower inlet port on the side of the column. After ascending though the column, the gas and liquid flows passed through the granular activated carbon bed. Afterwards, the liquid flow was collected through one of the outlets downstream of the GAC packed bed.

The ozone concentration in the gas phase was measured with a BMT 964C ozone analyser (BMT MESSTECHNIK GMBH, Stahnsdorf, Germany) located on the side of the column. Dissolved ozone concentration and temperature were measured with a Rosemount 499AOZ-54 dissolved sensor (Emerson, Alcobendas, Spain). The $\mathrm{pH}$ value was recorded with a Rosemount Analytical model 399 sensor integrated into a Rosemount Analytical Solu Comp II recorder (Emerson). Residual ozone gas was removed using a Zonosistem thermocatalytic ozone destructor (Ingeniería del Ozono S.L.U, Cádiz, Spain).

Mass transfer characterization of the reactor was performed using deionized water in the presence of GAC, following a procedure previously described by Rodríguez et al. [37]. Operating conditions were kept similar to those used in the presence of phenol.

\subsection{Statistical Analysis}

The data were analysed with the SPSS software (IBM SPSS Statistics 27, SPSS Inc., Armonk, NY, USA). In each set of experiments, each experiment was performed in triplicate. Then, the relative standard deviation $(R S E, \%)$ of the data corresponding to conversions between 5 and $95 \%$ was calculated for the operational conditions established by Equation (30) [56]. Each measurement was replicated at least six times, and further replicates were carried out when the variation between each measurement exceeded $5 \%$ :

$$
R S E=\sqrt{\frac{\sum_{i=1}^{N}\left(\frac{C_{\exp }-C_{\bmod }}{C_{\exp }}\right)^{2}}{N-1}} \times 100
$$

\section{Conclusions}

A three-phase reaction kinetic model (Ad/Ox) for the description of G-L transfer within the liquid and on the catalyst's surface during the adsorption and ozonisation steps has been proposed. The model allows us to analyse catalytic ozonation, in the presence of GAC, for the removal of phenolic waters in a continuous process.

The combination of the simultaneous adsorption and ozonation processes with GAC resulted in an improvement of both phenol degradation kinetics and mineralisation efficiency, compared with an ozonation or adsorption process alone. The Ad/Ox kinetic model was verified via the experimental results of the catalytic ozonation process under a wide variety of operating conditions affecting the adsorption phenomena, the mass transfer, and the chemical reaction itself, providing a good fit with the experimental data, with a residual standard error of no more than $5 \%$ in most cases.

The estimation of the oxidation constants allowed us to study the role of GAC in the ozonisation process and its interaction with phenol. Depending on the degree of phenol dissociation, as a function of $\mathrm{pH}$, the reactivity of ozone was different. At an alkaline $\mathrm{pH}$ (values over 11.0), greater degradation and mineralisation were obtained, with kinetic constants of $0.20 \mathrm{~min}^{-1}$ and $2.1 \times 10^{-3}\left(\mathrm{mg} \mathrm{L}^{-1}\right)\left(\mathrm{mg} \mathrm{g}^{-1} \mathrm{GAC} \mathrm{min}\right)^{-1}$ for the liquid and solid, respectively. The use of an ozone dose above a critical value of $19.0 \mathrm{mg} \mathrm{L}^{-1}$ limited the kinetics and adsorption capacity of phenol, and its oxidation products by extension, leading to a decrease in mineralisation efficiency. On the other hand, at moderated ozone doses, a stronger influence of GAC adsorption mechanisms was observed, as the kinetic constant of the solid increased slightly to $k_{2}=2.4 \times 10^{-3}\left(\mathrm{mg} \mathrm{L}^{-1}\right)\left(\mathrm{mg} \mathrm{g}^{-1} \text { GAC min }\right)^{-1}$. 
Increases in the pressure and gas flow rate did not lead to significant improvements, due to the insufficiency of the excess ozone transferred.

The most favourable operating conditions for the enhancement of the catalytic and adsorptive action of GAC were $\mathrm{pH}=11.0$, ozone dose $=19.0 \mathrm{mg} \mathrm{L}^{-1}$, gas flow rate $=0.4 \mathrm{~L} \mathrm{~h}^{-1}$ and pressure $=2.5 \mathrm{~atm}$. The GAC adsorbed the pollutant, subsequently exposing the phenol to attacks by ozone through the hydroxyl radicals generated on its surface. Consequently, the most favourable phenol removal conditions may involve a balance between the radicalgenerating and adsorptive functions of GAC.

The proposed model could be applied for the prediction of the operating behaviour of a continuous fixed-bed system under different working conditions, making it easily scalable to the industrial level.

Supplementary Materials: The following are available online at https://www.mdpi.com/article/ 10.3390/catal11081014/s1. Table S1: Previous studies on the treatment of wastewater through catalytic ozonation processes in the presence of activated carbon. Figure S1: Evolution of ozone concentration at the reactor outlet gas stream. Figure S2: Determination of mass transfer coefficient of the experimental system for various pressures. Figure S3: Determination of mass transfer coefficient of the experimental system for various ozone flow rates. Figure $\mathrm{S}_{4}: \mathrm{I}_{3}{ }^{-}$concentration as a function of time for $0.1 \mathrm{M} \mathrm{KI}$. Figure S5: Analysis of the main degradation by-products during catalytic ozonation of phenol.

Author Contributions: J.I.L., A.d.L. and C.F. performed the conceptualisation; A.d.L., N.V. and J.I.L. carried out the design of the methodology and analyses; C.F. and N.V. contributed to the model validation; C.F., N.V. and L.M.C. carried out the formal analysis; C.F. and A.d.L. performed the investigation; C.F., J.I.L. and L.M.C. prepared the original draft; J.M.L., C.F. and N.V. reviewed and edited the manuscript; J.I.L. and A.d.L. supervised the experimentation; J.I.L., N.V. and J.M.L. acquired the funding. All authors have read and agreed to the published version of the manuscript.

Funding: The authors are grateful to the University of the Basque Country for their financial support of this study through the GIU20/56 project and C. Ferreiro's predoctoral PIF grant (PIF16/367).

Acknowledgments: The authors are thankful for the technical and human support provided by General X-ray Service and Macrobehaviour-Mesostructure-Nanotechnology Service of the General Research Services (SGIker) of the UPV/EHU.

Conflicts of Interest: The authors declare no conflict of interest.

\section{Nomenclature}

$\varepsilon \quad$ Bed porosity, $\mathrm{m}^{3} \mathrm{~m}^{-3}$

$v \quad$ Linear velocity of fluid flow, $\mathrm{cm} \mathrm{min}^{-1}$

A Reactor cross-sectional area, $\mathrm{cm}^{2}$

$\mathrm{C}^{*} \mathrm{O}_{3, \mathrm{~L}} \quad$ Concentration of ozone in the equilibrium with the ozone adsorbed on the activated carbon, $\mathrm{mg} \mathrm{L}^{-1}$

$\mathrm{C}^{*} \mathrm{O}_{3, \mathrm{~s}}$ Concentration of ozone on the catalyst in equilibrium with the liquid ozone concentration, $\mathrm{mg} \mathrm{L}^{-1}$

$C_{\mathrm{p}}^{*} \quad$ Calculated pollutant concentration in the liquid in terms of total organic carbon, $\mathrm{mg} \mathrm{L}^{-1}$

$C_{\exp } \quad$ Experimental pollutant concentration in the liquid, $\mathrm{mg} \mathrm{L}^{-1}$

$\mathrm{C}_{\text {mod }} \quad$ Modelled pollutant concentration in the liquid, $\mathrm{mg} \mathrm{L}^{-1}$

$\mathrm{C}_{\mathrm{O}_{3}, \mathrm{G}} \quad$ Concentrations of ozone in the gas phase, $\mathrm{mg} \mathrm{L}^{-1}$

$\mathrm{C}_{\mathrm{O}_{3}, \mathrm{~L}} \quad$ Ozone concentration in liquid, $\mathrm{mg} \mathrm{L}^{-1}$

$C_{\mathrm{p}} \quad$ Pollutant concentration in the liquid, $\mathrm{mg} \mathrm{L}^{-1}$

$D_{\mathrm{L}} \quad$ Axial dispersion coefficient, $\mathrm{cm}^{2} \mathrm{~min}^{-1}$

$F_{\mathrm{G}} \quad$ Ozone mass flow, $\mathrm{g} \mathrm{O}_{3} \mathrm{~h}^{-1}$

$F_{\mathrm{P}} \quad$ Phenol mass flow, $\mathrm{g} \mathrm{h}^{-1}$

$\mathrm{He} \quad$ Henry's constant, bar $\mathrm{L} \mathrm{mg}^{-1}$

$k_{1} \quad$ Kinetic oxidation constant of phenol in the liquid, $\mathrm{min}^{-1}$

$k_{2} \quad$ Kinetic oxidation constant of phenol in the solid, $\left(\mathrm{mg} \mathrm{L}^{-1}\right)\left(\mathrm{mg} \mathrm{g}^{-1} \mathrm{GAC} \min \right)^{-1}$ 


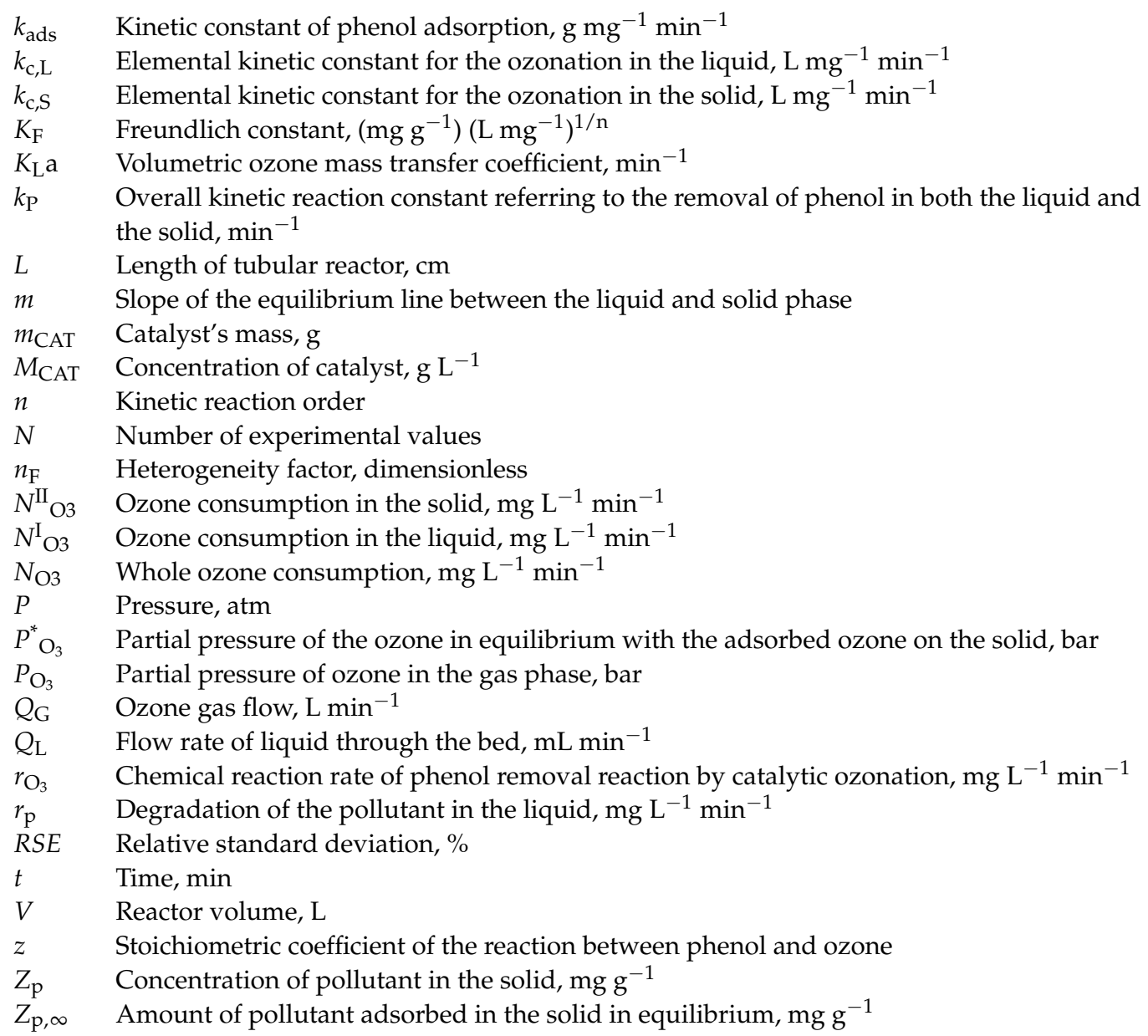

\section{References}

1. Akadiri, S.S.; Alola, A.A.; Alola, U.V.; Nwambe, C.S. The role of ecological footprint and the changes in degree days on environmental sustainability in the USA. Environ. Sci. Pollut. Res. 2020, 27, 24929-24938. [CrossRef]

2. Aitken, D.; Rivera, D.; Godoy-Faúndez, A.; Holzapfel, E. Water Scarcity and the Impact of the Mining and Agricultural Sectors in Chile. Sustainability 2016, 8, 128. [CrossRef]

3. Electronic Code of Federal Regulations (eCFR). Available online: https://www.ecfr.gov/ (accessed on 27 April 2021).

4. European Comission. Directive 2000/60/EC of the European Parliament and of the Council of 23 October 2000 Establishing a Framework for Community Action in the Field of Water Policy. Official Journal 2000, 327, 00001-0073. Available online: data.europa.eu/eli/dir/2000/60/oj (accessed on 22 December 2000).

5. United Nations About the Sustainable Development Goals. Available online: https://www.un.org/sustainabledevelopment/ sustainable-development-goals/ (accessed on 7 February 2020).

6. de Arruda Guelli Ulson de Souza, S.M.; de Souza, F.B.; Ulson de Souza, A.A. Application of Individual and Simultaneous Ozonation and Adsorption Processes in Batch and Fixed-Bed Reactors for Phenol Removal. Ozone Sci. Eng. 2012, 34, $259-268$. [CrossRef]

7. US EPA. Contaminant Candidate List 4-CCL 4. Available online: https://www.epa.gov/ccl/contaminant-candidate-list-4-ccl-4-0 (accessed on 9 October 2018).

8. Babich, H.; Davis, D.L. Phenol: A review of environmental and health risks. Regul. Toxicol. Pharmacol. 1981, 1, 90-109. [CrossRef]

9. Ribeiro, H.B.; Bampi, J.; da Silva, T.C.; Dervanoski, A.; Milanesi, P.M.; Fuzinatto, C.F.; de Mello, J.M.M.; da Luz, C.; Vargas, G.D.L.P. Study of phenol biodegradation in different agitation systems and fixed bed column: Experimental, mathematical modeling, and numerical simulation. Environ. Sci. Pollut. Res. 2020, 27, 45250-45269. [CrossRef]

10. Esplugas, S.; Giménez, J.; Contreras, S.; Pascual, E.; Rodríguez, M. Comparison of different advanced oxidation processes for phenol degradation. Water Res. 2002, 36, 1034-1042. [CrossRef]

11. Sumalatha, B.; Narayana, A.V.; Kumar, K.K.; Babu, D.J.; Venkateswarulu, T.C. Phenol Removal from Industrial Effluent Using Emulsion Liquid Memebranes. J. Pharm. Sci. Res. 2016, 8, 307-312.

12. Chen, L.; Xu, Y.; Sun, Y. Combination of Coagulation and Ozone Catalytic Oxidation for Pretreating Coking Wastewater. Int. J. Environ. Res. Public Health 2019, 16, 1705. [CrossRef]

13. Pradeep, N.V.; Anupama, S.; Navya, K.; Shalini, H.N.; Idris, M.; Hampannavar, U.S. Biological removal of phenol from wastewaters: A mini review. Appl. Water Sci. 2015, 5, 105-112. [CrossRef] 
14. Klibanov, A.M.; Tu, T.M.; Scott, K.P. Peroxidase-catalyzed removal of phenols from coal-conversion waste waters. Science 1983, 221, 259-261. [CrossRef]

15. Bevilaqua, J.V.; Cammarota, M.C.; Freire, D.M.G.; Sant'Anna Jr., G.L. Phenol removal through combined biological and enzymatic treatments. Braz. J. Chem. Eng. 2002, 19, 151-158. [CrossRef]

16. De Luis, A.M.; Lombraña, J.I.; Menéndez, A.; Sanz, J. Analysis of the Toxicity of Phenol Solutions Treated with $\mathrm{H}_{2} \mathrm{O}_{2} / \mathrm{UV}$ and $\mathrm{H}_{2} \mathrm{O}_{2} / \mathrm{Fe}$ Oxidative Systems. Ind. Eng. Chem. Res. 2011, 50, 1928-1937. [CrossRef]

17. Ferreiro, C.; Villota, N.; de Luis, A.; Lombrana, J.I. Analysis of the effect of the operational variants in a combined adsorptionozonation process with granular activated carbon for the treatment of phenol wastewater. React. Chem. Eng. 2020, 5, 760-778. [CrossRef]

18. Salvestrini, S.; Fenti, A.; Chianese, S.; Iovino, P.; Musmarra, D. Diclofenac sorption from synthetic water: Kinetic and thermodynamic analysis. J. Environ. Chem. Eng. 2020, 8, 104105. [CrossRef]

19. Erto, A.; Chianese, S.; Lancia, A.; Musmarra, D. On the mechanism of benzene and toluene adsorption in single-compound and binary systems: Energetic interactions and competitive effects. Desalin. Water Treat. 2017, 86, 259-265. [CrossRef]

20. Rout, P.R.; Zhang, T.C.; Bhunia, P.; Surampalli, R.Y. Treatment technologies for emerging contaminants in wastewater treatment plants: A review. Sci. Total Environ. 2021, 753, 141990. [CrossRef] [PubMed]

21. Rathi, B.S.; Kumar, P.S.; Show, P.-L. A review on effective removal of emerging contaminants from aquatic systems: Current trends and scope for further research. J. Hazard. Mater. 2021, 409, 124413. [CrossRef]

22. Von Sonntag, C.; Von Gunten, U. Chemistry of Ozone in Water and Wastewater Treatment: From Basic Principles to Applications; Iwa Publishing: London, UK, 2012; ISBN 978-1-84339-313-9.

23. Jamshidi, N.; Torabian, A.; Azimi, A.; Ghadimkhani, A. Degradation of Phenol in Aqueous Solution by Advanced Oxidation Process. Asian J. Chem. 2009, 21, 673-681.

24. Ferreiro, C.; Villota, N.; Lombraña, J.I.; Rivero, M.J. Heterogeneous Catalytic Ozonation of Aniline-Contaminated Waters: A Three-Phase Modelling Approach Using $\mathrm{TiO}_{2} / \mathrm{GAC}$. Water 2020, 12, 3448. [CrossRef]

25. Ameta, S. Advanced Oxidation Processes for Wastewater Treatment: Emerging Green Chemical Technology; Elsevier Science: San Diego, CA, USA, 2018; ISBN 978-0-12-810499-6.

26. Beltran, F.J. Ozone Reaction Kinetics for Water and Wastewater Systems; CRC Press: Boca Raton, FL, USA, 2003; ISBN 978-0-203-50917-3.

27. Rodríguez, A.; Rosal, R.; Perdigón-Melón, J.A.; Mezcua, M.; Agüera, A.; Hernando, M.D.; Letón, P.; Fernández-Alba, A.R.; García-Calvo, E. Ozone-Based Technologies in Water and Wastewater Treatment. In Emerging Contaminants from Industrial and Municipal Waste; Barceló, D., Petrovic, M., Eds.; Springer: Berlin/Heidelberg, Germany, 2008; Volume 5S/2, pp. 127-175, ISBN 978-3-540-79209-3.

28. Nawrocki, J. Catalytic ozonation in water: Controversies and questions. Discussion paper. Appl. Catal. B Environ. 2013, 142-143, 465-471. [CrossRef]

29. Nawrocki, J.; Kasprzyk-Hordern, B. The efficiency and mechanisms of catalytic ozonation. Appl. Catal. B Environ. 2010, 99, 27-42. [CrossRef]

30. Guo, Y.; Yang, L.; Wang, X. The Application and Reaction Mechanism of Catalytic Ozonation in Water Treatment. J. Environ. Anal. Toxicol. 2012, 2, 2161-0525. [CrossRef]

31. Criegee, R. Mechanism of Ozonolysis. Angew. Chem. Int. Ed. Engl. 1975, 14, 745-752. [CrossRef]

32. Lin, S.H.; Wang, C.H. Ozonation of phenolic wastewater in a gas-induced reactor with a fixed granular activated carbon bed. Ind. Eng. Chem. Res. 2003, 42, 1648-1653. [CrossRef]

33. Xiong, W.; Chen, N.; Feng, C.; Liu, Y.; Ma, N.; Deng, J.; Xing, L.; Gao, Y. Ozonation catalyzed by iron-and/or manganesesupported granular activated carbons for the treatment of phenol. Environ. Sci. Pollut. Res. Int. 2019, 26, 21022-21033. [CrossRef]

34. Shukla, S.; Kisku, G. Linear and Non-Linear Kinetic Modeling for Adsorption of Disperse Dye in Batch Process. Res. J. Environ. Toxicol. 2015, 9, 320-331. [CrossRef]

35. Ferreiro, C.; Gómez-Motos, I.; Lombraña, J.I.; de Luis, A.; Villota, N.; Ros, O.; Etxebarria, N. Contaminants of Emerging Concern Removal in an Effluent of Wastewater Treatment Plant under Biological and Continuous Mode Ultrafiltration Treatment. Sustainability 2020, 12, 725. [CrossRef]

36. Alhamed, Y.A. Adsorption kinetics and performance of packed bed adsorber for phenol removal using activated carbon from dates' stones. J. Hazard. Mater. 2009, 170, 763-770. [CrossRef]

37. Rodriguez, C.; Lombrana, J.I.; de Luis, A.; Sanz, J. Oxidizing efficiency analysis of an ozonation process to degrade the dye rhodamine 6G. J. Chem. Technol. Biotechnol. 2017, 92, 656-665. [CrossRef]

38. Gottschalk, C.; Saupe, A.; Libra, J.A. Ozonation of Water and Waste Water: A practical Guide to Understanding Ozone and Its Application; Wiley-VCH: Weinheim, Germany, 2010. [CrossRef]

39. Chaichanawong, J.; Yamamoto, T.; Ohmori, T. Enhancement effect of carbon adsorbent on ozonation of aqueous phenol. J. Hazard. Mater. 2010, 175, 673-679. [CrossRef] [PubMed]

40. Ferreiro, C.; Villota, N.; Lombraña, J.I.; Rivero, M.J.; Zúñiga, V.; Rituerto, J.M. Analysis of a Hybrid Suspended-Supported Photocatalytic Reactor for the Treatment of Wastewater Containing Benzothiazole and Aniline. Water 2019, 11, 337. [CrossRef] 
41. Rekhate, C.V.; Srivastava, J.K. Recent advances in ozone-based advanced oxidation processes for treatment of wastewater-A review. Chem. Eng. J. Adv. 2020, 3, 100031. [CrossRef]

42. Chand, R.; Molina, R.; Johnson, I.; Hans, A.; Bremner, D.H. Activated carbon cloth: A potential adsorbing/oxidizing catalyst for phenolic wastewater. Water Sci. Technol. J. Int. Assoc. Water Pollut. Res. 2010, 61, 2817-2823. [CrossRef]

43. Beltrán, F.J.; Rivas, F.J.; Montero-de-Espinosa, R. Mineralization improvement of phenol aqueous solutions through heteroeneous catalytic ozonation. J. Chem. Technol. Biotechnol. 2003, 78, 1225-1233. [CrossRef]

44. Byun, S.; Cho, S.H.; Yoon, J.; Geissen, S.U.; Vogelpohl, A.; Kim, S.M. Influence of mass transfer on the ozonation of wastewater from the glass fiber industry. Water Sci. Technol. J. Int. Assoc. Water Pollut. Res. 2004, 49, 31-36. [CrossRef]

45. Rosen, H.M. Use of Ozone and Oxygen in Advanced Wastewater Treatment. J. Water Pollut. Control Fed. 1973, 45, 2521-2536.

46. Buhler, R.; Staehelin, J.; Hoigne, J. Ozone Decomposition in Water Studied by Pulse-Radiolysis $1 . \mathrm{HO}_{2} / \mathrm{O}_{2}{ }^{-}$and $\mathrm{HO}_{3} / \mathrm{O}_{3}{ }^{-}$as Intermediates. J. Phys. Chem. 1984, 88, 2560-2564. [CrossRef]

47. Nawaz, F.; Cao, H.; Xie, Y.; Xiao, J.; Chen, Y.; Ghazi, Z.A. Selection of active phase of $\mathrm{MnO}_{2}$ for catalytic ozonation of 4-nitrophenol. Chemosphere 2017, 168, 1457-1466. [CrossRef]

48. Yang, L.; Sheng, M.; Li, Y.; Xue, W.; Li, K.; Cao, G. A hybrid process of Fe-based catalytic ozonation and biodegradation for the treatment of industrial wastewater reverse osmosis concentrate. Chemosphere 2020, 238, 124639. [CrossRef] [PubMed]

49. Hu, E.; Wu, X.; Shang, S.; Tao, X.; Jiang, S.; Gan, L. Catalytic ozonation of simulated textile dyeing wastewater using mesoporous carbon aerogel supported copper oxide catalyst. J. Clean. Prod. 2016, 112, 4710-4718. [CrossRef]

50. Lin, S.H.; Wang, C.H. Adsorption and catalytic oxidation of phenol in a new ozone reactor. Environ. Technol. 2003, 24, 1031-1039. [CrossRef] [PubMed]

51. Ribao, P.; Rivero, M.J.; Ortiz, I. $\mathrm{TiO}_{2}$ structures doped with noble metals and/or graphene oxide to improve the photocatalytic degradation of dichloroacetic acid. Environ. Sci. Pollut. Res. Int. 2017, 24, 12628-12637. [CrossRef]

52. Kaledin, L.A.; Tepper, F.; Kaledin, T.G. Pristine point of zero charge (p.p.z.c.) and zeta potentials of boehmite's nanolayer and nanofiber surfaces. Int. J. Smart Nano Mater. 2016, 7, 1-21. [CrossRef]

53. Wu, C.; Liu, X.; Wei, D.; Fan, J.; Wang, L. Photosonochemical degradation of Phenol in water. Water Res. 2001, 35, $3927-3933$. [CrossRef]

54. Association, A.P.H. Standard Methods for the Examination of Water and Wastewater; American Public Health Association: Washington, DC, USA, 2005; ISBN 978-0-87553-047-5.

55. Alfonso-Muniozguren, P.; Ferreiro, C.; Richard, E.; Bussemaker, M.; Lombraña, J.I.; Lee, J. Analysis of Ultrasonic Pre-treatment for the Ozonation of Humic Acids. Ultrason. Sonochem. 2020, 71, 105359. [CrossRef]

56. Sanchez, M.; Rivero, M.J.; Ortiz, I. Kinetics of dodecylbenzenesulphonate mineralisation by $\mathrm{TiO}_{2}$ photocatalysis. Appl. Catal. B Environ. 2011, 101, 515-521. [CrossRef] 